\title{
A systematic review of the use of health services by immigrants and native populations
}

Antonio Sarría-Santamera ${ }^{1,2,3,4^{*}}$, Ana Isabel Hijas-Gómez ${ }^{5,6}$, Rocío Carmona ${ }^{2,3}$ and Luís Andrés Gimeno-Feliú 1,7,8,9

\author{
* Correspondence: asarria@isciii.es \\ ${ }^{1}$ Red de Investigación en Servicios \\ de Salud y Enfermedades Crónicas, \\ Madrid, Spain \\ ${ }^{2}$ National School of Public Health, \\ Institute of Health Carlos III, Madrid, \\ Spain \\ Full list of author information is \\ available at the end of the article
}

\begin{abstract}
Background: Changes in migration patterns that have occurred in recent decades, both quantitative, with an increase in the number of immigrants, and qualitative, due to different causes of migration (work, family reunification, asylum seekers and refugees) require constant $u$ pdating of the analysis of how immigrants access health services. Understanding of the existence of changes in use patterns is necessary to adapt health services to the new socio-demographic reality. The aim of this study is to describe the scientific evidence that assess the differences in the use of health services between immigrant and native populations.
\end{abstract}

Methods: A systematic review of the electronic database MEDLINE (PubMed) was conducted with a search of studies published between June 2013 and February 2016 that addressed the use of health services and compared immigrants with native populations. MeSH terms and key words comprised Health Services Needs and Demands/Accessibility/Disparities/Emigrants and Immigrants/Native/Ethnic Groups. The electronic search was supplemented by a manual search of grey literature. The following information was extracted from each publication: context of the study (place and year), characteristics of the included population (definition of immigrants and their sub-groups), methodological domains (design of the study, source of information, statistical analysis, variables of health care use assessed, measures of need, socio-economic indicators) and main results.

Results: Thirty-six publications were included, 28 from Europe and 8 from other countries. Twenty-four papers analysed the use of primary care, 17 the use of specialist services (including hospitalizations or emergency care), 18 considered several levels of care and 11 assessed mental health services. The characteristics of immigrants included country of origin, legal status, reasons for migration, length of stay, different generations and socio-demographic variables and need. In general, use of health services by the immigrants was less than or equal to the native population, although some differences between immigrants were also identified.

Conclusions: This review has identified that immigrants show a general tendency towards a lower use of health services than native populations and that there are significant differences within immigrant sub-groups in terms of their patterns of utilization. Further studies should include information categorizing and evaluating the diversity within the immigrant population.

Keywords: Access to health care, Immigrants and native born

\section{Biomed Central}

(c) The Author(s). 2016 Open Access This article is distributed under the terms of the Creative Commons Attribution 4.0 International License (http://creativecommons.org/licenses/by/4.0/), which permits unrestricted use, distribution, and reproduction in any medium, provided you give appropriate credit to the original author(s) and the source, provide a link to the Creative Commons license, and indicate if changes were made. The Creative Commons Public Domain Dedication waiver (http://creativecommons.org/ publicdomain/zero/1.0/) applies to the data made available in this article, unless otherwise stated. 


\section{Background}

The number of international migrants continues to grow each year. According to the United Nations Migration Report, the number of migrants has reached 244 million in 2015 up from 191 million in 2005, representing an increase of $28 \%$ over the decade in comparison with an increase of 13\% during the period 1990-2000 [1, 2].

Between 2000 and 2015, Europe has absorbed the second largest number of international migrants following Asia [1,3]. Despite the global economic crisis which started in 2007-2008, Europe and Northern America have recorded an annual growth rate in the international migrant stock of $2 \%$ per year [1].

These transformations have both quantitative (i.e. an increasing number of migrants) and qualitative (i.e. evolving reasons for migration) aspects. There is a trend towards permanent migration and reunification of families with immigrant setting in the host country in a more definitive way [4]. And most recently, we have seen an increasing number of asylum seekers and refugees, which is reaching the highest levels seen since World War II [1].

This situation has generated various responses in the host countries, as immigration is acquiring a significant social and political dimension. Immigration is influencing public opinion and triggering a debate, often improperly informed, regarding the pressure on public services-including health services [3]. This has even led to the adoption of new legislation [5-7] limiting access to health care for migrants, that may pose, as a result, a risk to public health.

The dramatic changes in demographics, socio-economics and politics require an update of the analysis of health service utilization by immigrants in order to properly determine the breadth and scope of the current situation. Consequently, research on migrant access and utilization of health services has proliferated in recent decades $[8,9]$. Results from a previous review point to a lower utilization rate of general and specialist medical services by immigrants compared to native-born populations [10]. However, and since patterns of healthcare utilization depend on factors that may have evolved in recent years, such as age, sex, socio-economic level, time of stay in the host country or origin of the immigrants, and the specific features of healthcare services of the host countries, it seems necessary to revisit the state of knowledge on this subject.

The objective of this study is to describe the available scientific evidence that has investigated the differences in healthcare service utilization between immigrant and native populations in the last 3 years (June 2013 through February 2016), and to explore the possible effect on the differential use of variables associated with health needs, socio-economic status or other factors.

\section{Methods}

A systematic literature review was performed to identity the available empirical evidence comparing immigrant's healthcare utilization with native populations using a predefined protocol [10]. Inclusion criteria for articles to be considered were original studies with quantitative data that compared the use of healthcare services between native and immigrant populations. Service use was defined as the interaction between health professionals and patients [11]. Only studies with both population groups properly defined, i.e. immigrant and native, were included. For the purposes of this review, we used the European Union definition of immigrant status based on foreign country of birth including up to the second generation [12]. 
Papers that considered undocumented immigrants, asylum seekers and/or refugees were also included. The indigenous majority population served as the native reference group. No limitation in gender or ethnic characteristics was stipulated.

Articles were excluded if they (1) exclusively evaluated healthcare utilization for children or adolescents younger than 18 years of age, (2) were editorials, letters or reviews and (3) were qualitative studies.

\section{Search strategy and study selection}

Two strategies were utilized in the search for relevant articles on this review.

Firstly, in February 2016, a librarian conducted a systematic review of the electronic database MEDLINE (PubMed) in search of the literature published between June 2013 and February 2016. No language restrictions were applied; no authors were contacted for additional information. MeSH terms and key words used, as well as search strategies performed, are shown in Table 1.

The initial screening of the articles was based on abstracts. Two researchers reviewed all abstracts independently. Selection of relevant articles was based on the information obtained from the abstracts and was agreed upon in discussion. If the abstract was not available, the full text was examined. In the case of discrepancies between the two researchers, the original paper was obtained and an agreement was achieved after it was read.

Secondly, a researcher (AIHG) conducted a manual search of grey literature through Google Scholar, including published papers from 2013 through February 2016 taking into account the terms (Health care use; Comparison; Immigrants; Natives) and (Needs, demands and barriers; Coverage; Primary care; Emergency services; Utilization patterns; Native; Foreign; Autochthonous; Immigrant). Both English and Spanish web pages were included in the search results. Appropriateness for inclusion was based on titles; in the event of doubt, abstracts were retrieved. Studies without electronic abstracts were not included.

Subsequently, two researchers examined the full text of all papers that satisfied the inclusion criteria (AIHG, ASS).

\section{Data extraction}

The following information were extracted from each publication: context of the study (country and year), characteristics of the included population (definition of native and immigrants groups, sample size for each group), methodological components (design of the study, statistical analysis, source of information), area of healthcare services assessed, confounders affecting healthcare utilization (individual determinants, measures of need, socio-economic indicators, cultural factors), objective of the study and main results.

\section{Results}

\section{Characteristics of the studies}

Thirty-six papers met the inclusion criteria in this study. The process followed to include those papers is shown in Fig. 1. Table 2 shows the information extracted from the included publications. Of the 36 studies included, 8 were duplicated in both the manual and electronic search [13-20], 12 were included after the manual search [21-32] and 16 through the electronic search [33-48]. Among them, at least 9 partly describe the 
Table 1 Search strategy for healthcare service utilization's comparative studies

\begin{tabular}{|c|c|c|}
\hline \multicolumn{3}{|l|}{ General practitioner use (electronic search): } \\
\hline 1. Health Services Needs and Demand/ & 12. health services [Title] & 23. $18-22$ / OR \\
\hline 2. Health Status/ & 13. Primary care [Title] & 24. immigrant* [Title] \\
\hline 3. Health Services Accessibility/ & 14. Emergency services [Title] & 25. migrant* $[$ Title] \\
\hline 4. Coverage [Title] & 15. Utilization patterns [Title] & 26. Ethnic Groups [Title] \\
\hline 5. $1-4 / O R$ & 16. 6-15/ OR & 27. $24-26 / O R$ \\
\hline 6. health care [Title] & 17.5 and 16 & 28. 23 and 27 \\
\hline 7. health disparities [Title] & 18. Emigration and Immigration/ & $\begin{array}{l}\text { 29. Health AND utilization AND } \\
\text { immigrant* }^{*} \text { [itle] }\end{array}$ \\
\hline 8. access to care [Title] & 19. Emigrants and Immigrants/ & 30. 17 AND 28 \\
\hline 9. health resources [Title] & 20. Native [Title] & 31. 29 or 30 (GPs precise search) \\
\hline 10. health profiles [Title] & 21. Foreign [Title] & $\begin{array}{l}\text { 32. (16 AND 27) OR } 29 \\
\text { (GPs exhaustive search) }\end{array}$ \\
\hline 11. health status [Title] & 22. Autochthonous [Title] & \\
\hline \multicolumn{3}{|l|}{ Specialist use (electronic search): } \\
\hline 1. Health Services/utilization/ & 7. Emigrants and Immigrants/ & 13. Specialization/ \\
\hline 2. Health Services Accessibility/ & 8. Ethnic Groups & 14. speciali* [TI] \\
\hline 3. Health Status/ & 9. Native [Title] & 15. 13 OR 14 \\
\hline 4. Coverage [Title] & 10. Foreign [Title] & 16. 5 AND 12 AND 15 \\
\hline 5. $1-4 / O R$ & 11. Autochthonous [Title] & \\
\hline 6. Emigration and Immigration/ & 12. $6-11 / O R$ & \\
\hline
\end{tabular}

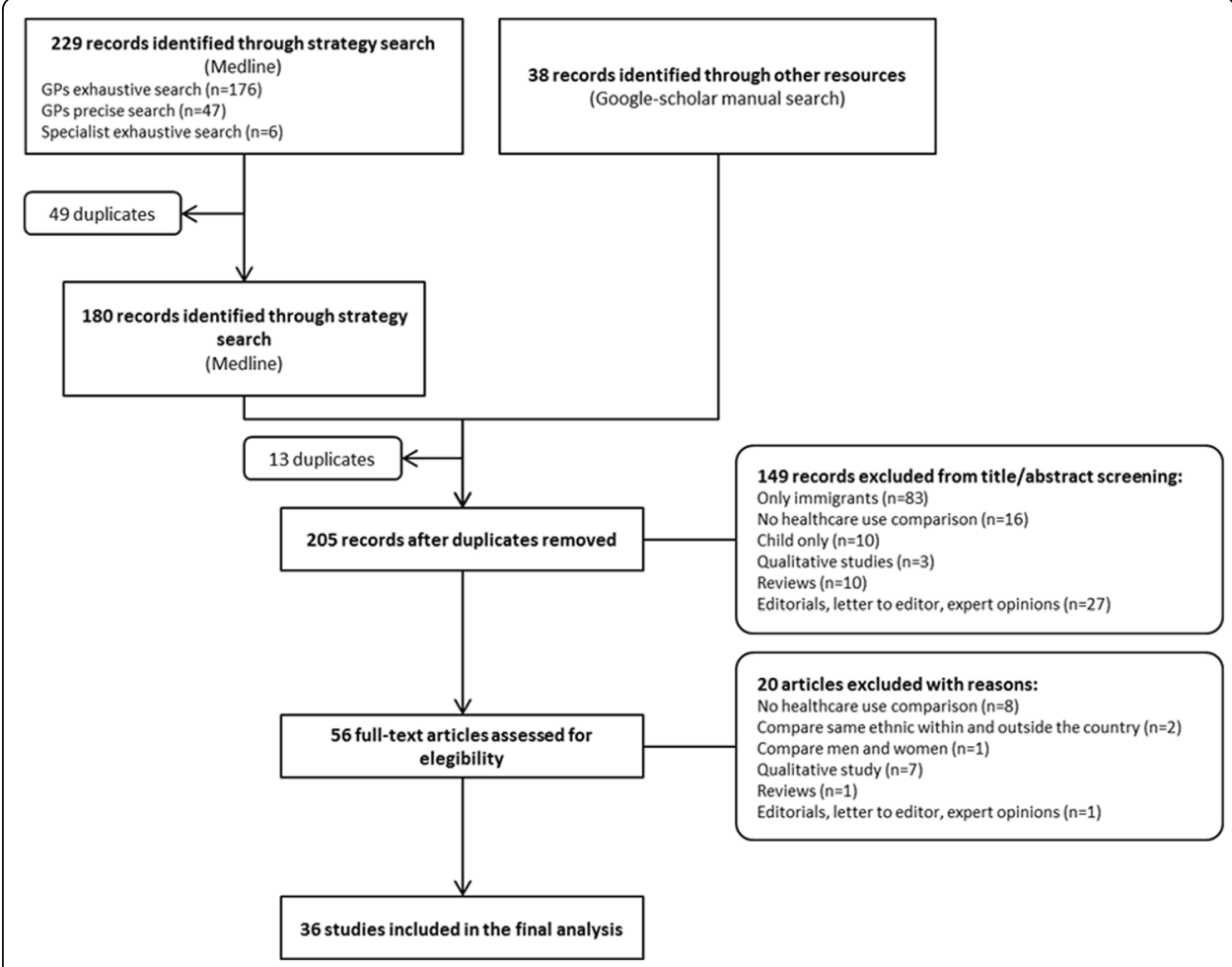

Fig. 1 Study flowchart for the selection process of the final included studies 
Table 2 Descriptive summary of the studies included in the review

\begin{tabular}{|c|c|c|c|c|c|c|c|c|c|c|}
\hline Reference & Country & Year & Sample & Objectives & $\begin{array}{l}\text { Information } \\
\text { sources }\end{array}$ & $\begin{array}{l}\text { Dependent } \\
\text { variable }\end{array}$ & $\begin{array}{l}\text { Independent } \\
\text { variable (migrant } \\
\text { definition) }\end{array}$ & $\begin{array}{l}\text { Need } \\
\text { indicators }\end{array}$ & $\begin{array}{l}\text { Socio- } \\
\text { economic } \\
\text { indicators }\end{array}$ & Results \\
\hline $\begin{array}{l}\text { Almeida LM } \\
\text { et al. [33] } \\
2014\end{array}$ & Portugal & 2012 & $\begin{array}{l}277 \text { women } \\
\text { Migrants } \\
(n=89) \\
\text { Portuguese } \\
(n=188)\end{array}$ & $\begin{array}{l}\text { To evaluate differences } \\
\text { in obstetric care } \\
\text { between immigrant } \\
\text { and native women } \\
\text { in a country with free } \\
\text { access to health care }\end{array}$ & $\begin{array}{l}\text { Register and } \\
\text { survey-based study } \\
\text { (1) Administrative } \\
\text { databases of the } \\
\text { four public } \\
\text { maternity } \\
\text { hospitals (February } \\
1 \text { and December } 31 \text {, } \\
\text { 2012) (2) Telephone } \\
\text { survey }\end{array}$ & $\begin{array}{l}\text { (1) First } \\
\text { appointment at } \\
>12 \text { weeks (2) } \\
\text { Number of prenatal } \\
\text { visits }\end{array}$ & $\begin{array}{l}\text { (1) Native: born } \\
\text { in Portugal (2) } \\
\text { Immigrant: born } \\
\text { outside Portugal } \\
\text { with both } \\
\text { parents born } \\
\text { outside Portugal }\end{array}$ & Age Parity & $\begin{array}{l}\text { Family income } \\
\text { Education level } \\
\text { Marital status }\end{array}$ & $\begin{array}{l}\text { Migrants were } \\
\text { more prone to } \\
\text { late prenatal care } \\
\text { (first pregnancy } \\
\text { appointment after } \\
12 \text { weeks of } \\
\text { pregnancy, to } \\
\text { have fewer than } \\
\text { three prenatal } \\
\text { visits) }\end{array}$ \\
\hline $\begin{array}{l}\text { Beiser M } \\
\text { et al. [21] } \\
2014\end{array}$ & Canada & 2009-2010 & $\begin{array}{l}98,346 \text { individuals } \\
\text { Native born } \\
(n=83,949) \\
\text { Established } \\
\text { migrants }(n=10,810) \\
\text { Recent immigrants } \\
(n=3587) \\
20-74 \text { years }\end{array}$ & $\begin{array}{l}\text { To examine the effects } \\
\text { of chronic health } \\
\text { conditions, as well as } \\
\text { personal resources and } \\
\text { regional context on } \\
\text { labour force } \\
\text { participation, receipt } \\
\text { of government transfer } \\
\text { payments and use of } \\
\text { health services by short- } \\
\text { and long-stay } \\
\text { immigrants compared } \\
\text { with native-born } \\
\text { Canadians }\end{array}$ & $\begin{array}{l}\text { Survey-based study } \\
\text { Canada Community } \\
\text { Health Survey } \\
\text { (CCHS) }\end{array}$ & $\begin{array}{l}\text { (1) GP visits in the } \\
\text { past } 12 \text { months (2) } \\
\text { Labour force } \\
\text { participation (3) } \\
\text { Use of government } \\
\text { transfer payments }\end{array}$ & $\begin{array}{l}\text { (1) Native-born } \\
\text { Canadians (2) } \\
\text { Recent } \\
\text { immigrants } \\
\text { (resident in } \\
\text { Canada for } \\
10 \text { years or less) } \\
\text { (3) Established } \\
\text { immigrants } \\
\text { (present in } \\
\text { Canada for } \\
\text { more than } \\
10 \text { years) }\end{array}$ & $\begin{array}{l}\text { Age \& gender } \\
\text { Chronic } \\
\text { physical } \\
\text { conditions } \\
\text { (last } 6 \text { months } \\
\text { or more) } \\
\text { Chronic } \\
\text { mental } \\
\text { conditions }\end{array}$ & $\begin{array}{l}\text { Education level } \\
\text { Marital status } \\
\text { Official-language } \\
\text { ability (English or } \\
\text { French) Geographic } \\
\text { region }\end{array}$ & $\begin{array}{l}\text { Recent } \\
\text { immigrants } \\
\text { healthy or with } \\
\text { chronic health } \\
\text { problems made } \\
\text { fewer GP visits } \\
\text { Established } \\
\text { immigrants } \\
\text { with chronic } \\
\text { conditions did } \\
\text { not differ in } \\
\text { their use of GP }\end{array}$ \\
\hline $\begin{array}{l}\text { Berchet C } \\
{[22]} \\
2013\end{array}$ & France & 2006-08 & $\begin{array}{l}12,999 \text { individuals } \\
\text { French }(n=11,934) \\
\text { Immigrants } \\
(n=1065) \geq 18 \text { years }\end{array}$ & $\begin{array}{l}\text { To highlight factors } \\
\text { generating healthcare } \\
\text { use inequalities relating } \\
\text { to immigration }\end{array}$ & $\begin{array}{l}\text { Survey-based study } \\
\text { Health Survey } \\
\text { (l'Enquête sur la } \\
\text { santé et la protection } \\
\text { sociale-ESPS) }\end{array}$ & $\begin{array}{l}\text { (1) GP visits (last } \\
\text { year) (2) Specialist } \\
\text { medical visits } \\
\text { (last year) }\end{array}$ & $\begin{array}{l}\text { Nationality and } \\
\text { country of birth } \\
\text { (subject and } \\
\text { parents) }\end{array}$ & $\begin{array}{l}\text { Age \& gender } \\
\text { Self-rated } \\
\text { health } \\
\text { Chronic disease } \\
\text { and functional } \\
\text { limitations } \\
\text { Health } \\
\text { behaviour } \\
\text { (smoke, } \\
\text { overweight) }\end{array}$ & $\begin{array}{l}\text { Health insurance } \\
\text { Education level } \\
\text { Employment status } \\
\text { Family composition } \\
\text { Isolation and social } \\
\text { support Place of } \\
\text { residence GP's } \\
\text { and specialist's } \\
\text { patient load }\end{array}$ & $\begin{array}{l}\text { Immigrants } \\
\text { present a lower } \\
\text { demand for GP } \\
\text { and specialist care }\end{array}$ \\
\hline
\end{tabular}


Table 2 Descriptive summary of the studies included in the review (Continued)

\begin{tabular}{|c|c|c|c|c|c|c|c|c|c|c|}
\hline $\begin{array}{l}\text { Carmona- } \\
\text { Alférez MR } \\
\text { [23] } \\
2013\end{array}$ & $\begin{array}{l}\text { Spain } \\
\text { (Madrid) }\end{array}$ & 2006-2007 & $\begin{array}{l}835,401 \text { individuals } \\
\text { Natives }(n=694,716) \\
\text { Immigrants } \\
(n=140,685) \\
25-64 \text { years }\end{array}$ & $\begin{array}{l}\text { To evaluate the } \\
\text { relationship between } \\
\text { birthplace of users of } \\
\text { PHC in the Community } \\
\text { of Madrid (CM) and } \\
\text { the referrals to } \\
\text { specialists }\end{array}$ & $\begin{array}{l}\text { Register-based study } \\
\text { Medical records of } \\
\text { PHC (OMI-AP) }\end{array}$ & $\begin{array}{l}\text { (1) Referral to } \\
\text { specialists (2) } \\
\text { Number of referrals }\end{array}$ & Country of birth & $\begin{array}{l}\text { Age \& gender } \\
\text { Health problems } \\
\text { (last } 12 \text { months) } \\
\text { Number of visits } \\
\text { to the GP (last } \\
12 \text { months) } \\
\text { Territorial per } \\
\text { capital income } \\
\text { GP's patient } \\
\text { load }\end{array}$ & - & $\begin{array}{l}\text { Immigrants from } \\
\text { South America } \\
\text { had higher } \\
\text { probability to } \\
\text { be referred for } \\
\text { any health problem, } \\
\text { while Asiatic } \\
\text { immigrants have } \\
\text { the lowest overall } \\
\text { probability of } \\
\text { referrals } \\
\text { Immigrants from } \\
\text { Western countries, } \\
\text { Central America } \\
\text { and the Caribbean } \\
\text { showed similar } \\
\text { referral rates to } \\
\text { Spanish natives }\end{array}$ \\
\hline $\begin{array}{l}\text { De Back TR } \\
\text { et al. [34] } \\
2015\end{array}$ & Netherlands & 2009-2010 & $\begin{array}{l}60,852 \text { patients with } \\
\text { hypertension, } \\
\text { ischemic heart disease, } \\
\text { cerebrovascular } \\
\text { accidents and cardiac } \\
\text { failure Native Dutch } \\
(n=55,320) \\
\text { Immigrant Moluccan } \\
\text { immigrant }(n=5532)\end{array}$ & $\begin{array}{l}\text { To determine the } \\
\text { frequency of visits to } \\
\text { the medical specialist } \\
\text { and GP and the } \\
\text { prescription of } \\
\text { cardiovascular agents } \\
\text { among Moluccans } \\
\text { compared to native } \\
\text { Dutch }\end{array}$ & $\begin{array}{l}\text { Register-based } \\
\text { study } \\
\text { Registry data from } \\
\text { the Achmea Health } \\
\text { Insurance Company } \\
\text { (Achmea) }\end{array}$ & $\begin{array}{l}\text { (1) Number of } \\
\text { GP visits (2) Number of } \\
\text { specialist (cardiologist } \\
\text { and neurologist) } \\
\text { visits }\end{array}$ & $\begin{array}{l}\text { Moluccan and } \\
\text { Dutch surnames }\end{array}$ & Age \& gender & $\begin{array}{l}\text { Socio-economic } \\
\text { status (SES) Area-level } \\
\text { SES scores were } \\
\text { composed by the } \\
\text { Netherlands Institute } \\
\text { for Social Research } \\
\text { Place of residence }\end{array}$ & $\begin{array}{l}\text { Cardiovascular } \\
\text { healthcare use } \\
\text { of ethnic minority } \\
\text { groups may } \\
\text { converge towards } \\
\text { that of the majority } \\
\text { population }\end{array}$ \\
\hline $\begin{array}{l}\text { De Luca G } \\
\text { et al. [24] } \\
2013\end{array}$ & Italy & 2004-2005 & $\begin{array}{l}102,857 \text { individuals } \\
\text { Natives }(n=97,229) \\
\text { Immigrants }(n=5628) \\
0-64 \text { years }\end{array}$ & $\begin{array}{l}\text { To explore differences } \\
\text { in utilization of health } \\
\text { services between the } \\
\text { immigrant and the } \\
\text { native-born } \\
\text { populations }\end{array}$ & $\begin{array}{l}\text { Survey-based study } \\
\text { Italian Health } \\
\text { Conditions survey } \\
\text { (ISTAT-Condizioni di } \\
\text { salute e Ricorso ai } \\
\text { Servizi Sanitari) }\end{array}$ & $\begin{array}{l}\text { (1) GP visits (last } \\
4 \text { weeks) (2) } \\
\text { Specialist medical } \\
\text { visits (last } 4 \text { weeks) } \\
\text { (3) Phone } \\
\text { consultations } \\
\text { (last } 4 \text { weeks) } \\
\text { (4) ED care visits } \\
\text { (last } 4 \text { weeks) }\end{array}$ & $\begin{array}{l}\text { Country of birth } \\
\text { and citizenship } \\
\text { criteria (1) Native } \\
\text { (Italian citizens } \\
\text { born in Italy) (2) } \\
\text { First-generation } \\
\text { immigrants } \\
\text { (individuals born } \\
\text { outside of Italy } \\
\text { without Italian } \\
\text { citizenship) (3) }\end{array}$ & $\begin{array}{l}\text { Age \& gender } \\
\text { Self-assessed } \\
\text { family wealth } \\
\text { Self-assessed } \\
\text { health status } \\
\text { Chronic } \\
\text { diseases and } \\
\text { disability } \\
\text { conditions } \\
\text { Health } \\
\text { behaviour }\end{array}$ & $\begin{array}{l}\text { Education level } \\
\text { Marital status } \\
\text { Employment status } \\
\text { Number of children } \\
\text { in the household } \\
\text { Area of residence }\end{array}$ & $\begin{array}{l}\text { Immigrants tend } \\
\text { to use specialist } \\
\text { services and have } \\
\text { telephone } \\
\text { consultations } \\
\text { less frequently, } \\
\text { whereas they } \\
\text { use ED services } \\
\text { more often }\end{array}$ \\
\hline
\end{tabular}


Table 2 Descriptive summary of the studies included in the review (Continued)

\begin{tabular}{|c|c|c|c|c|c|c|c|c|c|c|}
\hline & & & & & & & $\begin{array}{l}\text { Second- } \\
\text { generation } \\
\text { immigrants } \\
\text { (individuals born } \\
\text { in Italy without } \\
\text { Italian citizenship) } \\
\text { (4) Naturalized } \\
\text { Italians (individuals } \\
\text { born outside of } \\
\text { Italy with Italian } \\
\text { citizenship) }\end{array}$ & $\begin{array}{l}\text { (smoke, } \\
\text { weight-checking, } \\
\text { physical activity) }\end{array}$ & & \\
\hline $\begin{array}{l}\text { Díaz E } \\
\text { et al. [13] } \\
2015\end{array}$ & Norway & 2008 & $\begin{array}{l}25,915 \text { patients } \\
\text { diagnosed with } \\
\text { dementia or memory } \\
\text { impairment in PHC } \\
\text { Natives }(n=25,117) \\
\text { Immigrants } \\
(n=788) \geq 50 \text { years }\end{array}$ & $\begin{array}{l}\text { To study utilization of } \\
\text { primary healthcare } \\
\text { services of Norwegians } \\
\text { and immigrants with } \\
\text { either a diagnosis of } \\
\text { dementia or memory } \\
\text { impairment }\end{array}$ & $\begin{array}{l}\text { Register-based study } \\
\text { (1) National } \\
\text { Population Register- } \\
\text { NPR (2) Norwegian } \\
\text { Health Economics } \\
\text { Administration } \\
\text { database-HELFO (3) } \\
\text { Norwegian } \\
\text { Prescription } \\
\text { Database-NorPD }\end{array}$ & $\begin{array}{l}\text { (1) Number of GP } \\
\text { visits (2) ED visits } \\
\text { (3) Home } \\
\text { consultations }\end{array}$ & $\begin{array}{l}\text { Country of } \\
\text { birth. (Born } \\
\text { abroad with } \\
\text { both parents } \\
\text { from abroad) }\end{array}$ & Age \& gender & $\begin{array}{l}\text { Education level } \\
\text { Marital status } \\
\text { Length of stay } \\
\text { in Norway } \\
\text { Place of residence }\end{array}$ & $\begin{array}{l}\text { No differences } \\
\text { in the use of } \\
\text { PHC were found }\end{array}$ \\
\hline $\begin{array}{l}\text { Díaz E } \\
\text { et al. [14] } \\
2014\end{array}$ & Norway & 2008 & $\begin{array}{l}3,739,244 \text { individuals } \\
\text { Natives }(n=3,349,721) \\
\text { Immigrants } \\
(n=389,523) \\
\geq 15 \text { years }\end{array}$ & $\begin{array}{l}\text { To describe and } \\
\text { compare the use } \\
\text { and frequency of } \\
\text { use of PHC services } \\
\text { between immigrants } \\
\text { and natives in Norway } \\
\text { To investigate the } \\
\text { importance of } \\
\text { morbidity burden, } \\
\text { socio-economic status } \\
\text { and length of stay in } \\
\text { Norway for immigrants' } \\
\text { use of PHC services }\end{array}$ & $\begin{array}{l}\text { Register-based study } \\
\text { (1) National } \\
\text { Population Register } \\
\text { (2) Norwegian Health } \\
\text { Economics } \\
\text { Administration } \\
\text { database-HELFO }\end{array}$ & $\begin{array}{l}\text { (1) Percentage of } \\
\text { each population } \\
\text { who had used the } \\
\text { PHC system (GPS, } \\
\text { EPC and both) in } \\
2008 \text { (2) Frequency } \\
\text { of use among PHC } \\
\text { users }\end{array}$ & $\begin{array}{l}\text { Country of birth } \\
\text { (1) Natives (born } \\
\text { in Norway with } \\
\text { both parents born } \\
\text { in Norway) (2) } \\
\text { Immigrants } \\
\text { (born abroad with } \\
\text { both parents from } \\
\text { abroad) staying at } \\
\text { least } 6 \text { months, } \\
\text { divided according } \\
\text { to the World Bank } \\
\text { income categories } \\
\text { of their country of } \\
\text { origin }\end{array}$ & $\begin{array}{l}\text { Age \& gender } \\
\text { Morbidity } \\
\text { groups } \\
\text { (Johns Hopkins } \\
\text { University } \\
\text { Adjusted } \\
\text { Clinical Groups) }\end{array}$ & $\begin{array}{l}\text { Education level } \\
\text { Marital status } \\
\text { Income level } \\
\text { Place of residence }\end{array}$ & $\begin{array}{l}\text { Significantly } \\
\text { fewer immigrants } \\
\text { from all but LIC } \\
\text { used their GP } \\
\text { and all PHC } \\
\text { services, but a } \\
\text { higher share of } \\
\text { immigrants } \\
\text { except those } \\
\text { from HIC used } \\
\text { the EPC. This } \\
\text { higher use did } \\
\text { not compensate } \\
\text { for less use of } \\
\text { GPs in terms of } \\
\text { overall use of PHC } \\
\text { Among GP users, } \\
\text { however, } \\
\text { immigrants used } \\
\text { the GP at a } \\
\text { statistically }\end{array}$ \\
\hline
\end{tabular}




\begin{tabular}{|c|c|c|c|c|c|c|c|c|c|c|}
\hline & & & & & & & & & & $\begin{array}{l}\text { significant higher } \\
\text { rate compared } \\
\text { with natives } \\
\text { Immigrants } 65 \\
\text { years from all but } \\
\text { HIC used GPS less } \\
\text { than other age } \\
\text { groups, and the } \\
\text { same was true for } \\
\text { overall use of PHC, } \\
\text { although older } \\
\text { immigrants from } \\
\text { LIC used the EPC } \\
\text { most The use of } \\
\text { PHC services, but } \\
\text { not the rate of use } \\
\text { increased with } \\
\text { length of stay } \\
\text { in Norway }\end{array}$ \\
\hline $\begin{array}{l}\text { Díaz E } \\
\text { et al. [15] } \\
2014\end{array}$ & Norway & 2008 & $\begin{array}{l}1,605,873 \text { individuals } \\
\text { Natives }(n=1,516,012) \\
\text { Immigrants }(n=89,861) \\
\geq 50 \text { years }\end{array}$ & $\begin{array}{l}\text { To describe the } \\
\text { utilization of PHC in } \\
\text { Norway in terms of } \\
\text { number of consultations, } \\
\text { diagnoses given and } \\
\text { procedures } \\
\text { undertaken To compare } \\
\text { native Norwegians' use } \\
\text { of PHC services with } \\
\text { that of different } \\
\text { immigrant groups }\end{array}$ & $\begin{array}{l}\text { Register-based study } \\
\text { (1) National } \\
\text { Population Register } \\
\text { (2) Norwegian Health } \\
\text { Economics } \\
\text { Administration } \\
\text { database-HELFO }\end{array}$ & $\begin{array}{l}\text { (1) Frequency of } \\
\text { use of PHC system } \\
(G P, E P C) \text { in } 2008 \\
\text { (2) Diagnoses } \\
\text { received at GP and } \\
\text { EPC consultations }\end{array}$ & $\begin{array}{l}\text { Country of birth } \\
\text { (1) Natives (born } \\
\text { in Norway with } \\
\text { both parents born } \\
\text { in Norway) ( } 2 \text { ) } \\
\text { Immigrants (born } \\
\text { abroad with both } \\
\text { parents from } \\
\text { abroad) staying at } \\
\text { least } 6 \text { months, } \\
\text { divided according } \\
\text { to the World Bank } \\
\text { income categories } \\
\text { of their country of } \\
\text { origin }\end{array}$ & $\begin{array}{l}\text { Age \& gender } \\
\text { Morbidity } \\
\text { groups (Johns } \\
\text { Hopkins } \\
\text { University } \\
\text { Adjusted } \\
\text { Clinical Groups) }\end{array}$ & $\begin{array}{l}\text { Education level } \\
\text { Marital status } \\
\text { Income level } \\
\text { Length of stay } \\
\text { in Norway Place } \\
\text { of residence } \\
\text { Reason for } \\
\text { migration Age } \\
\text { at migration }\end{array}$ & $\begin{array}{l}\text { A lower proportion } \\
\text { of HIC immigrants } \\
\text { used PHC, but } \\
\text { utilization was } \\
\text { increasingly } \\
\text { similar in older } \\
\text { age groups } \\
\text { The mean number } \\
\text { of consultations } \\
\text { to both the GP } \\
\text { and the EPC, and } \\
\text { the mean number } \\
\text { of different } \\
\text { diagnoses for } \\
\text { PHC users were } \\
\text { higher for } 50 \text { to } \\
65 \text { years old OIC } \\
\text { immigrants, but } \\
\text { this pattern was } \\
\text { reversed for older } \\
\text { adults }\end{array}$ \\
\hline $\begin{array}{l}\text { Durbin A } \\
\text { et al. [25] }\end{array}$ & $\begin{array}{l}\text { Canada } \\
\text { (Ontario) }\end{array}$ & 1993-2012 & $\begin{array}{l}\text { 1,820,443 individuals } \\
\text { Long-term residents }\end{array}$ & $\begin{array}{l}\text { Examine the use of } \\
\text { primary care and }\end{array}$ & Register-based study & $\begin{array}{l}\text { 1) Visits to PHC } \\
\text { physicians 2) Visits }\end{array}$ & $\begin{array}{l}\text { Country of birth } \\
\text { (1) Long-term }\end{array}$ & Age \& gender & $\begin{array}{l}\text { Education level } \\
\text { Marital status }\end{array}$ & $\begin{array}{l}\text { Immigrants were } \\
\text { more or less likely }\end{array}$ \\
\hline
\end{tabular}


Table 2 Descriptive summary of the studies included in the review (Continued)

\begin{tabular}{|c|c|c|c|c|c|c|c|c|c|c|}
\hline 2015 & & & $\begin{array}{l}(n=908,329) \text { Immigrants } \\
(n=912,114) 18-105 \\
\text { years }\end{array}$ & $\begin{array}{l}\text { specialty services for } \\
\text { non-psychotic mental } \\
\text { health disorders by } \\
\text { immigrants to Ontario } \\
\text { Canada during their } \\
\text { first } 5 \text { years after arrival }\end{array}$ & $\begin{array}{l}\text { (1) OHIP claims data } \\
\text { (2) Canadian } \\
\text { Institute for Health } \\
\text { Information's } \\
\text { Discharge Abstract } \\
\text { Database (3) Ontario } \\
\text { Mental Health } \\
\text { Reporting System (4) } \\
\text { National Ambulatory } \\
\text { Care Reporting } \\
\text { System (April 1, } \\
\text { 1993-March 31, } \\
\text { 2012) }\end{array}$ & $\begin{array}{l}\text { to psychiatrists } 3 \text { ) } \\
\text { Composite of ED } \\
\text { visits or hospital } \\
\text { admissions }\end{array}$ & $\begin{array}{l}\text { residents } \\
\text { (newcomer before } \\
1985 \text { and Canadian- } \\
\text { born) (2) Immigrants } \\
\text { (identified through } \\
\text { the Ontario } \\
\text { Citizenship and } \\
\text { Immigration } \\
\text { Canada (CIC) } \\
\text { database) }\end{array}$ & & $\begin{array}{l}\text { Income level } \\
\text { Length of stay } \\
\text { Official language } \\
\text { speaking ability } \\
\text { Immigrant admission } \\
\text { category } \\
\text { Neighbourhood }\end{array}$ & $\begin{array}{l}\text { to access primary } \\
\text { mental health care } \\
\text { depending on the } \\
\text { world region of } \\
\text { origin } \\
\text { Regarding specialty } \\
\text { mental health care } \\
\text { (psychiatry and } \\
\text { hospital care), } \\
\text { immigrants used } \\
\text { it less. Across the } \\
3 \text { mental health } \\
\text { services, estimates } \\
\text { of use by } \\
\text { immigrant region } \\
\text { groups were } \\
\text { among the lowest } \\
\text { for newcomers } \\
\text { from East Asian } \\
\text { and Pacific and } \\
\text { among the highest } \\
\text { for persons from } \\
\text { Middle East and } \\
\text { North Africa }\end{array}$ \\
\hline $\begin{array}{l}\text { Durbin A } \\
\text { et al. [16] } \\
2014\end{array}$ & $\begin{array}{l}\text { Canada } \\
\text { (Ontario) }\end{array}$ & 2002-2012 & $\begin{array}{l}359,673 \text { individuals } \\
\text { LT-Residents } \\
\text { ( } n=163,263) \\
\text { Immigrants } \\
(n=163,298) \\
18-105 \text { years }\end{array}$ & $\begin{array}{l}\text { To compare service } \\
\text { use (primary care visits, } \\
\text { visits for psychiatric } \\
\text { care, and hospital use) } \\
\text { for non-psychotic } \\
\text { mental disorders } \\
\text { by recent immigrants } \\
\text { by matched long-term } \\
\text { residents }\end{array}$ & $\begin{array}{l}\text { Register-based study } \\
\text { (1) OHIP claims data } \\
\text { (2) Canadian Institute } \\
\text { for Health } \\
\text { Information's } \\
\text { Discharge Abstract } \\
\text { Database (3) Ontario } \\
\text { Mental Health } \\
\text { Reporting System (4) } \\
\text { National Ambulatory } \\
\text { Care Reporting } \\
\text { System }\end{array}$ & $\begin{array}{l}\text { (1) Visits to PHC } \\
\text { physicians (2) Visits } \\
\text { to psychiatrists (3) } \\
\text { Composite of ED } \\
\text { visits or hospital } \\
\text { admissions }\end{array}$ & $\begin{array}{l}\text { Country of birth } \\
\text { (1) Long-term } \\
\text { residents } \\
\text { (newcomer before } \\
1985 \text { and } \\
\text { Canadian-born) } \\
\text { (2) Immigrants } \\
\text { (identified through } \\
\text { the Ontario } \\
\text { Citizenship and } \\
\text { Immigration } \\
\text { Canada (CIC) } \\
\text { database) }\end{array}$ & Age \& gender & $\begin{array}{l}\text { Education level } \\
\text { Income level } \\
\text { Official language } \\
\text { speaking ability } \\
\text { Immigrant } \\
\text { admission } \\
\text { category } \\
\text { Neighbourhood }\end{array}$ & $\begin{array}{l}\text { Immigrants in all } \\
\text { admission classes } \\
\text { and of both sexes } \\
\text { were generally less } \\
\text { likely to use all } \\
\text { three types of } \\
\text { mental health } \\
\text { service. The } \\
\text { exceptions were } \\
\text { for primary mental } \\
\text { health care, where } \\
\text { male refugees were } \\
\text { more likely to } \\
\text { have at least one } \\
\text { visit For PHC, } \\
\text { estimates of } \\
\text { intensity of use } \\
\text { were highest for }\end{array}$ \\
\hline
\end{tabular}


Table 2 Descriptive summary of the studies included in the review (Continued)

\begin{tabular}{|c|c|c|c|c|c|c|c|c|c|c|}
\hline & & & & & & & & & & $\begin{array}{l}\text { refugees and } \\
\text { lowest for economic } \\
\text { class immigrants For } \\
\text { psychiatric care and } \\
\text { hospital care, } \\
\text { estimates were } \\
\text { similar across } \\
\text { admission class } \\
\text { groups }\end{array}$ \\
\hline $\begin{array}{l}\text { Esscher A } \\
\text { et al. [35] } \\
2014\end{array}$ & Sweden & 1988-2010 & $\begin{array}{l}74 \text { individuals Natives } \\
(n=48) \text { Immigrants } \\
(n=26)\end{array}$ & $\begin{array}{l}\text { To identify suboptimal } \\
\text { factors of maternity } \\
\text { care related to } \\
\text { maternal death } \\
\text { as it occurred in } \\
\text { Sweden over a period } \\
\text { of increased migration } \\
\text { of childbearing women } \\
\text { from LIC and MIC }\end{array}$ & $\begin{array}{l}\text { Register-based study } \\
\text { (1) Swedish official } \\
\text { and national } \\
\text { registries (1988- } \\
\text { 2007) (2) Swedish } \\
\text { Society of Obstetrics } \\
\text { and Gynaecology } \\
\text { (SFOG) Maternal } \\
\text { Mortality Group } \\
\text { (2008-2010) }\end{array}$ & $\begin{array}{l}\text { Factors of } \\
\text { suboptimal } \\
\text { care (1) Delay of } \\
\text { care-seeking } \\
\text { (non-compliance, } \\
\text { late booking) (2) } \\
\text { Accessibility of } \\
\text { services (language } \\
\text { proficiency, legal } \\
\text { status, transport) } \\
\text { (3) Quality of care } \\
\text { (Insufficient } \\
\text { surveillance and } \\
\text { delayed treatment, } \\
\text { miscommunication } \\
\text { between providers, } \\
\text { limited use of } \\
\text { resources) }\end{array}$ & $\begin{array}{l}\text { Country of birth } \\
\text { divided according } \\
\text { to the World Bank } \\
\text { Income categories } \\
\text { (1) LIC (Ethiopia, } \\
\text { Eritrea, Somalia, } \\
\text { Democratic } \\
\text { Republic of Congo, } \\
\text { Zimbabwe, Gambia, } \\
\text { and Pakistan) } \\
\text { (2) MIC (Poland, } \\
\text { Former Yugoslavia, } \\
\text { Turkey, } \\
\text { Iran, Iraq, Morocco, } \\
\text { Philippines, and } \\
\text { Thailand) }\end{array}$ & $\begin{array}{l}\text { Age Causes } \\
\text { of death }\end{array}$ & - & $\begin{array}{l}\text { Suboptimal care } \\
\text { was a significantly } \\
\text { more frequent } \\
\text { contributing } \\
\text { factor of maternal } \\
\text { death for the } \\
\text { foreign-born } \\
\text { women. Many of } \\
\text { these deaths were } \\
\text { associated with } \\
\text { communication- } \\
\text { related barriers } \\
\text { and delays in } \\
\text { care-seeking } \\
\text { Immigrant lower } \\
\text { health coverage } \\
\text { represents the first } \\
\text { factor generating } \\
\text { inequalities in the } \\
\text { propensity to } \\
\text { contact a GP, } \\
\text { while education } \\
\text { and income are } \\
\text { the most important } \\
\text { drivers of inequalities } \\
\text { in the propensity to } \\
\text { contact a specialist }\end{array}$ \\
\hline $\begin{array}{l}\text { Fosse- } \\
\text { Edorh S } \\
\text { et al. [36] } \\
2014\end{array}$ & France & $2002-2007$ & $\begin{array}{l}13,959 \text { individuals Born } \\
\text { in France }(n=12,711) \\
\text { Born in North Africa } \\
(n=327) \geq 45 \text { years }\end{array}$ & $\begin{array}{l}\text { The objective of the } \\
\text { present study was to } \\
\text { determine DT2 } \\
\text { prevalence and } \\
\text { management in } \\
\text { immigrants from }\end{array}$ & $\begin{array}{l}\text { Survey-based study } \\
\text { (1) Population-based } \\
\text { survey Enquête } \\
\text { décennale santé } \\
\text { (EDS; Decennial } \\
\text { Health Survey) 2002- }\end{array}$ & $\begin{array}{l}\text { (1)GP visits last year } \\
\text { (2) } \geq 1 \text { private } \\
\text { specialist } \\
\text { (ophthalmologist or } \\
\text { endocrinologist) visit } \\
\text { last year (3) }\end{array}$ & $\begin{array}{l}\text { Country of birth } \\
\text { (1) Born in France } \\
\text { (2) Born in North } \\
\text { Africa }\end{array}$ & $\begin{array}{l}\text { Age \& gender } \\
\text { Diabetes } \\
\text { complications } \\
\text { Smoking }\end{array}$ & $\begin{array}{l}\text { Education level } \\
\text { Financial difficulty }\end{array}$ & $\begin{array}{l}\text { Reflects a greater } \\
\text { prevalence of DT2, } \\
\text { poorer health } \\
\text { status and/or lower } \\
\text { quality of care in } \\
\text { this population }\end{array}$ \\
\hline
\end{tabular}


Table 2 Descriptive summary of the studies included in the review (Continued)

\begin{tabular}{|c|c|c|c|c|c|c|c|c|c|c|}
\hline & & & & $\begin{array}{l}\text { North Africa living in } \\
\text { France to ascertain } \\
\text { whether the higher } \\
\text { diabetes mortality } \\
\text { observed in this } \\
\text { population compared } \\
\text { with the French-born } \\
\text { population reflected a } \\
\text { higher prevalence of } \\
\text { DT2, poorer health } \\
\text { status and or lower } \\
\text { quality of care }\end{array}$ & $\begin{array}{l}2003 \text { (2) ENTRED } \\
\text { (Échantillon national } \\
\text { témoin représentati } \\
\text { des personnes } \\
\text { diabétiques; } \\
\text { National representative } \\
\text { sample of people with } \\
\text { diabetes) survey } 2007\end{array}$ & $\begin{array}{l}\text { Hospitalization }>24 \mathrm{~h} \\
\text { last year } 4 \text { ) Length } \\
\text { of stay of } \\
\text { hospitalization }\end{array}$ & & & & $\begin{array}{l}\text { Our present study } \\
\text { found no major } \\
\text { differences between } \\
\text { patient groups } \\
\text { in terms of medical } \\
\text { visits except for less } \\
\text { frequent } \mathrm{G} \text { and } \\
\text { more frequent } \\
\text { dentist visits in the } \\
\text { BNA population }\end{array}$ \\
\hline $\begin{array}{l}\text { Franchi C } \\
\text { et al. [37] } \\
2016\end{array}$ & $\begin{array}{l}\text { Italy } \\
\text { (Lombardy } \\
\text { region) }\end{array}$ & 2010 & $\begin{array}{l}51,016 \text { individuals } \\
\text { Natives }(n=25,508) \\
\text { Immigrants } \\
(n=25,508) \\
65-94 \text { years }\end{array}$ & $\begin{array}{l}\text { To compare healthcare } \\
\text { resource utilization } \\
\text { (drug prescriptions, } \\
\text { hospital admissions } \\
\text { and healthcare services) } \\
\text { in regular immigrants } \\
\text { living in the Lombardy } \\
\text { Region of Northern Italy } \\
\text { at least } 10 \text { years versus } \\
\text { native elderly people } \\
\text { (65 years or older) }\end{array}$ & $\begin{array}{l}\text { Register-based study } \\
\text { Administrative } \\
\text { databases of Lombardy } \\
\text { region (1) Anagraphic } \\
\text { database (2) Prescription } \\
\text { database (3) Hospital } \\
\text { discharge database } \\
\text { (4) Outpatient } \\
\text { prescriptions } \\
\text { by GP (healthcare } \\
\text { services utilization) }\end{array}$ & $\begin{array}{l}\text { Drug prescription } \\
\text { Polytherapy Hospital } \\
\text { admissions } \\
\text { Healthcare service } \\
\text { utilization }\end{array}$ & $\begin{array}{l}\text { (1) Regular } \\
\text { immigrant } \\
\text { (born in a country } \\
\text { other than Italy } \\
\text { and registered } \\
\text { with the Italian } \\
\text { NHS) (2) Native } \\
\text { (born in Lombardy) }\end{array}$ & Age \& gender & - & $\begin{array}{l}\text { Older immigrants } \\
\text { (65 years and older) } \\
\text { present } \\
\text { under-utilization } \\
\text { of healthcare } \\
\text { resources and } \\
\text { prescriptions drugs, } \\
\text { including those } \\
\text { from HIC European } \\
\text { countries Only } \\
\text { immigrants from } \\
\text { Eastern Europe } \\
\text { and Eastern Africa } \\
\text { have a higher } \\
\text { prevalence for } \\
\text { hospital admissions. } \\
\text { Only immigrants } \\
\text { from Northern } \\
\text { Africa have higher } \\
\text { rate of prescriptions }\end{array}$ \\
\hline $\begin{array}{l}\text { Garcia- } \\
\text { Subirats I } \\
\text { et al. [38] } \\
2014\end{array}$ & Spain & $\begin{array}{l}2006-2007 \\
\& 2011- \\
2012\end{array}$ & $\begin{array}{l}2006-2007 \\
21,818 \text { individuals } \\
\text { Natives }(n=18,504) \\
\text { Immigrants }(n=2893) \\
2011-2012 \\
15,200 \text { individuals } \\
(n=12,559) \\
\text { Immigrants }(n=2390) \\
16-59 \text { years }\end{array}$ & $\begin{array}{l}\text { To analyse the changes } \\
\text { in access to health care } \\
\text { and the determinants } \\
\text { of access among the } \\
\text { immigrant and } \\
\text { autochthonous } \\
\text { populations in Spain } \\
\text { between } 2006 \\
\text { and } 2012\end{array}$ & $\begin{array}{l}\text { Survey-based study } \\
\text { Spanish National } \\
\text { Health Survey (SNHS) } \\
\text { of 2006-2007 and the } \\
\text { SNHS of 2011-2012 }\end{array}$ & $\begin{array}{l}\text { (1) Unmet healthcare } \\
\text { need in the last } \\
12 \text { months (2) Visits } \\
\text { to a GP in the last } \\
4 \text { weeks (3) Visit to } \\
\text { a specialist in the } \\
\text { last } 4 \text { weeks (4) } \\
\text { Hospitalization in } \\
\text { the last year (5) ED } \\
\text { visits in the last year }\end{array}$ & $\begin{array}{l}\text { Country of birth } \\
\text { (low and middle- } \\
\text { income countries } \\
\text { according to the } \\
\text { World Bank Income } \\
\text { classification) }\end{array}$ & $\begin{array}{l}\text { Age \& gender } \\
\text { Self-rated } \\
\text { health, suffering } \\
\text { from a } \\
\text { chronic disease, } \\
\text { having suffered } \\
\text { an injury in the } \\
\text { past year }\end{array}$ & $\begin{array}{l}\text { Private health } \\
\text { insurance policy } \\
\text { Education level } \\
\text { Marital status } \\
\text { Employment } \\
\text { situation Social } \\
\text { class (following } \\
\text { classification of the } \\
\text { Spanish Society of } \\
\text { Epidemiology) }\end{array}$ & $\begin{array}{l}\text { In } 2012 \text { the } \\
\text { immigrant } \\
\text { population had a } \\
\text { higher prevalence } \\
\text { of visiting the GP } \\
\text { compared to } 2006 \\
\text { The immigrant } \\
\text { population } \\
\text { had a lower } \\
\text { prevalence of }\end{array}$ \\
\hline
\end{tabular}




\begin{tabular}{|c|c|c|c|c|c|c|c|c|c|c|}
\hline & & & & & & & & & $\begin{array}{l}\text { Length of stay } \\
\text { (Immigrants in the } \\
\text { SNHS 2011-2012) }\end{array}$ & $\begin{array}{l}\text { visiting the } \\
\text { specialist } \\
\text { both in } 2006 \text { and } \\
2012 \\
\text { The difference in } \\
\text { use } \\
\text { of ED decreased } \\
\text { slightly for both } \\
\text { groups and the } \\
\text { difference between } \\
\text { them was } \\
\text { maintained from } \\
2006 \text { to } 2012 ; \text { the } \\
\text { immigrant } \\
\text { population showed } \\
\text { a higher prevalence } \\
\text { of use of this care } \\
\text { level } \\
\text { No significant } \\
\text { differences were } \\
\text { found between } \\
\text { both populations } \\
\text { in terms of } \\
\text { hospitalizations }\end{array}$ \\
\hline $\begin{array}{l}\text { Gazard B } \\
\text { et al. [26] } \\
2015\end{array}$ & $\begin{array}{l}\text { United } \\
\text { Kingdom, } \\
\text { UK } \\
\text { (Southeast } \\
\text { London, } \\
\text { Lambeth } \\
\text { and } \\
\text { Southwark) }\end{array}$ & 2008-2010 & $\begin{array}{l}1698 \text { individuals } \\
\text { Non-immigrant } \\
(n=1010) \\
\text { Immigrants }(n=659) \\
\geq 16 \text { years }\end{array}$ & $\begin{array}{l}\text { (1) To describe the } \\
\text { socio-demographic } \\
\text { and socio-economic } \\
\text { differences between } \\
\text { migrants and } \\
\text { non-migrants as broad } \\
\text { groupings and by } \\
\text { ethnicity, as well as } \\
\text { within migrant groups } \\
\text { by length of residence } \\
\text { in the UK (2) To } \\
\text { investigate the } \\
\text { associations between } \\
\text { migration status } \\
\text { and health-related } \\
\text { outcomes, including } \\
\text { health behaviours, } \\
\text { functional limitations, }\end{array}$ & $\begin{array}{l}\text { Survey-based study } \\
\text { South East London } \\
\text { Community Health } \\
\text { (SELCoH) survey }\end{array}$ & $\begin{array}{l}\text { (1) Registration with } \\
\text { GP (2) Visits to a GP } \\
\text { for an emotional } \\
\text { problem in the last } \\
12 \text { months (3) Seen } \\
\text { a counsellor } \\
\text { or mental health } \\
\text { specialist in the last } \\
12 \text { months (4) Use } \\
\text { of hospital services } \\
\text { (accident and } \\
\text { emergency and } \\
\text { other outpatient } \\
\text { department) in the } \\
\text { last } 12 \text { months }\end{array}$ & $\begin{array}{l}\text { (1) Migration } \\
\text { status (2) Length } \\
\text { of residence in the } \\
\text { UK (3) First } \\
\text { language (4) } \\
\text { Reason for } \\
\text { migration (5) } \\
\text { Migration status } \\
\text { within each ethnic } \\
\text { group category }\end{array}$ & $\begin{array}{l}\text { Age \& gender } \\
\text { Ethnicity }\end{array}$ & $\begin{array}{l}\text { Educational level } \\
\text { Employment status } \\
\text { Household income } \\
\text { Migrant status } \\
\text { Length of residence }\end{array}$ & $\begin{array}{l}\text { Migrants who had } \\
\text { been in the UK for } \\
<5 \text { years, white } \\
\text { migrants and those } \\
\text { who migrated for } \\
\text { education or } \\
\text { work had increased } \\
\text { odds of not being } \\
\text { currently registered } \\
\text { with a GP } \\
\text { Migrants who had } \\
\text { been in the UK } \\
\text { for } 5-10 \text { years had } \\
\text { increased odds of } \\
\text { seeing a GP for } \\
\text { an emotional } \\
\text { problem. Those } \\
\text { who had resided }\end{array}$ \\
\hline
\end{tabular}


Table 2 Descriptive summary of the studies included in the review (Continued)

\begin{tabular}{|c|c|c|c|c|c|c|c|c|c|c|}
\hline & & & & $\begin{array}{l}\text { physical and mental } \\
\text { health status and } \\
\text { health service use (3) } \\
\text { To examine whether } \\
\text { and how the effect of } \\
\text { migration status } \\
\text { changes when it is } \\
\text { disaggregated by } \\
\text { length of residence, } \\
\text { first language,reason } \\
\text { for migration and } \\
\text { combined with } \\
\text { ethnicity }\end{array}$ & & & & & & $\begin{array}{l}\text { in the UK for }<5 \\
\text { years had } \\
\text { decreased odds } \\
\text { Those who had } \\
\text { migrated for } \\
\text { education had } \\
\text { increased odds of } \\
\text { visiting an } \\
\text { outpatient } \\
\text { department } \\
\text { compared to } \\
\text { non-migrants } \\
\text { decreased odds of } \\
\text { seeing a GP for an } \\
\text { emotional problem }\end{array}$ \\
\hline $\begin{array}{l}\text { Gimeno- } \\
\text { Feliu LA } \\
\text { et al. [27] } \\
2016\end{array}$ & $\begin{array}{l}\text { Spain } \\
\text { (Aragón) \& } \\
\text { Norway }\end{array}$ & $\begin{array}{l}\text { Norway } \\
2008 \text { \& } \\
\text { Spain } 2010\end{array}$ & $\begin{array}{l}\text { Native born: } \\
\text { Spain }(n=1,102,391) \\
\text { Norway }(n=4,351,084) \\
\text { Immigrants: } \\
\text { Spain }(n=35,851) \\
\text { Norway }(n=60,733)\end{array}$ & $\begin{array}{l}\text { Analyse all registered } \\
\text { pharmacological } \\
\text { treatments for } \\
\text { immigrants from } \\
\text { Poland, China, Morocco } \\
\text { and Colombia } \\
\text { compared to natives, } \\
\text { aiming to identify } \\
\text { patterns of drug use for } \\
\text { each immigrant group } \\
\text { compared to host } \\
\text { countries }\end{array}$ & $\begin{array}{l}\text { Register-based study } \\
\text { (1) Pharmaceutical } \\
\text { Billing Database in } \\
\text { Aragon (2) Norwegian } \\
\text { Prescription } \\
\text { Database-NorPD }\end{array}$ & Drug prescription & $\begin{array}{l}\text { Country of birth } \\
\text { (Poland, Chine, } \\
\text { Colombia \& } \\
\text { Morocco) }\end{array}$ & Age \& gender & - & $\begin{array}{l}\text { In the two countries } \\
\text { studied, the } \\
\text { proportion } \\
\text { of immigrants that } \\
\text { purchased drugs } \\
\text { was significantly } \\
\text { lower than that of } \\
\text { the corresponding } \\
\text { native population } \\
\text { Immigrants from } \\
\text { Morocco showed } \\
\text { the highest drug } \\
\text { purchase rates } \\
\text { in relation to } \\
\text { natives, especially } \\
\text { for antidepressants, } \\
\text { pain killers and } \\
\text { drugs for peptic } \\
\text { ulcer. } \\
\text { Immigrants from } \\
\text { China and Poland } \\
\text { showed lowest } \\
\text { purchasing rates, } \\
\text { while Colombians } \\
\text { where more similar } \\
\text { to host countries }\end{array}$ \\
\hline
\end{tabular}


Table 2 Descriptive summary of the studies included in the review (Continued)

\begin{tabular}{|c|c|c|c|c|c|c|c|c|c|c|}
\hline $\begin{array}{l}\text { Gimeno- } \\
\text { Feliu LA } \\
\text { et al. [39] } \\
2013\end{array}$ & $\begin{array}{l}\text { Spain } \\
\text { (Aragón) }\end{array}$ & 2007 & $\begin{array}{l}594,145 \text { individuals } \\
\text { Natives }(n=527,881) \\
\text { Immigrants }(n=66,264) \\
\text { All ages }\end{array}$ & $\begin{array}{l}\text { (1) To analyse the use } \\
\text { of primary care services } \\
\text { by immigrants } \\
\text { compared to Spanish } \\
\text { nationals, adjusted } \\
\text { by age and sex (2) To } \\
\text { analyse the differences } \\
\text { in frequency of visits } \\
\text { to primary care in } \\
\text { relation to geographic } \\
\text { origin }\end{array}$ & $\begin{array}{l}\text { Register-based study } \\
\text { Electronic medical } \\
\text { records register (OMI: } \\
\text { Computerized } \\
\text { Medical Office) }\end{array}$ & $\begin{array}{l}\text { (1) GP appointments } \\
\text { (2) Paediatric } \\
\text { appointments (3) } \\
\text { Nurse appointments } \\
\text { (4) Midwife } \\
\text { appointments (5) } \\
\text { Physiotherapy } \\
\text { appointments (6) } \\
\text { Dental appointments } \\
\text { (7) Social worker } \\
\text { appointments (8) } \\
\text { PHC team } \\
\text { appointments }\end{array}$ & Nationality & Age \& gender & - & $\begin{array}{l}\text { The immigrant } \\
\text { population makes } \\
\text { less use of PHC } \\
\text { services. This is } \\
\text { evident for all age } \\
\text { groups and } \\
\text { regardless of } \\
\text { immigrants' } \\
\text { countries of origin }\end{array}$ \\
\hline $\begin{array}{l}\text { Klaufus } L \\
\text { et al. [40] } \\
2014\end{array}$ & Netherlands & 2008 & $\begin{array}{l}14,131 \text { individuals } \\
\text { Native born } \\
(n=11,678) \text { Immigrants } \\
(n=2453)>14 \text { years }\end{array}$ & $\begin{array}{l}\text { To investigate ethnic } \\
\text { differences as a factor } \\
\text { in mental healthcare } \\
\text { consumption in } \\
\text { patients with medium } \\
\& \text { high risk of CMD } \\
\text { (common mental } \\
\text { disorders) and to } \\
\text { identify determinants } \\
\text { that may explain } \\
\text { possible ethnic } \\
\text { differences }\end{array}$ & $\begin{array}{l}\text { Survey-based study } \\
\text { Health survey } \\
\text { conducted by Public } \\
\text { Health Services } \\
\text { (Amsterdam, } \\
\text { Rotterdam, Utrecht } \\
\text { and the Hague) }\end{array}$ & $\begin{array}{l}\text { (1) GP visits } \\
\text { (last year) (2) Mental } \\
\text { health visit } \\
\text { (psychiatrist, } \\
\text { psychologist or a } \\
\text { mental health care } \\
\text { facility) last year }\end{array}$ & $\begin{array}{l}\text { Country of birth } \\
\text { (subject and } \\
\text { parents) } \\
\text { (1) Native Dutch } \\
\text { (2) First-generation } \\
\text { immigrant (foreign } \\
\text { born and almost } \\
\text { one parent } \\
\text { foreign born) } \\
\text { (2) Second- } \\
\text { generation } \\
\text { immigrant (born } \\
\text { in Netherland } \\
\text { with at least one } \\
\text { parent foreign } \\
\text { born) }\end{array}$ & $\begin{array}{l}\text { Age \& gender } \\
\text { Physical health } \\
\text { problems }\end{array}$ & $\begin{array}{l}\text { Education level } \\
\text { Marital status } \\
\text { Employment } \\
\text { status Financial } \\
\text { situation Social } \\
\text { loneliness }\end{array}$ & $\begin{array}{l}\text { Ethnic minority } \\
\text { groups contacted } \\
\text { the GP significantly } \\
\text { more often than } \\
\text { native Dutch } \\
\text { people, with the } \\
\text { exception of } \\
\text { Antillean/Aruban } \\
\text { immigrants } \\
\text { First-generation } \\
\text { immigrants tended } \\
\text { to contact the GP } \\
\text { more often than } \\
\text { second-generation } \\
\text { immigrants } \\
\text { The four ethnic } \\
\text { minority groups } \\
\text { visited a mental } \\
\text { healthcare } \\
\text { specialist more } \\
\text { often than the } \\
\text { Dutch; this } \\
\text { was significantly } \\
\text { higher among } \\
\text { the Turks }\end{array}$ \\
\hline
\end{tabular}


Table 2 Descriptive summary of the studies included in the review (Continued)

\begin{tabular}{|c|c|c|c|c|c|c|c|c|c|c|}
\hline $\begin{array}{l}\text { Kerkenaar } \\
\text { M et al. [41] } \\
2013\end{array}$ & Austria & $\begin{array}{l}\text { October } \\
2010- \\
\text { September } \\
2011\end{array}$ & $\begin{array}{l}3448 \text { individuals } \\
\text { Natives }(n=2930) \\
\text { Immigrants }(n=518) \\
\geq 15 \text { years }\end{array}$ & $\begin{array}{l}\text { To study: (1) the } \\
\text { prevalence of } \\
\text { dysphoric disorders } \\
\text { among different } \\
\text { groups of migrants } \\
\text { (first and second } \\
\text { generation from } \\
\text { different regions) in } \\
\text { comparison to the } \\
\text { native Austrian } \\
\text { population using } \\
\text { a validated } \\
\text { questionnaire (2) The } \\
\text { influence of } \\
\text { gender, socio-economic } \\
\text { factors, fluency of host } \\
\text { language and length } \\
\text { of stay in Austria on this } \\
\text { prevalence (3) The } \\
\text { utilization of healthcare } \\
\text { services of migrants and } \\
\text { Austrians with and } \\
\text { without a dysphoric } \\
\text { disorder }\end{array}$ & $\begin{array}{l}\text { Survey-based study } \\
\text { (Telephone survey ad } \\
\text { hoc and PHQ-4) }\end{array}$ & $\begin{array}{l}\text { (1) Visits to a GP in } \\
\text { the last } 4 \text { weeks (2) } \\
\text { Visits to specialists } \\
\text { in their own practices } \\
\text { in the last } 4 \text { weeks } \\
\text { (3) Out or inpatient } \\
\text { hospital care in the } \\
\text { last } 4 \text { weeks (4) } \\
\text { Prevalence of } \\
\text { dysphoric disorders }\end{array}$ & $\begin{array}{l}\text { Country of birth } \\
\text { and country of } \\
\text { birth of fathers }\end{array}$ & $\begin{array}{l}\text { Age \& gender } \\
\text { Chronic disease }\end{array}$ & $\begin{array}{l}\text { Education level } \\
\text { Employment status } \\
\text { Living area Persons } \\
\text { in house }\end{array}$ & $\begin{array}{l}\text { No significant } \\
\text { difference was } \\
\text { found in the } \\
\text { utilization of } \\
\text { healthcare services } \\
\text { associated with } \\
\text { dysphoric disorders, } \\
\text { except for a higher } \\
\text { utilization of } \\
\text { secondary/tertiary } \\
\text { care by female } \\
\text { migrants with a } \\
\text { dysphoric disorder } \\
\text { Immigrant males } \\
\text { without dysphoric } \\
\text { disorders had a } \\
\text { lower utilization } \\
\text { rate }\end{array}$ \\
\hline $\begin{array}{l}\text { Koopmans } \\
\text { GT et al. } \\
\text { [17] } \\
2013\end{array}$ & Netherlands & $2001-2003$ & $\begin{array}{l}9077 \text { individuals } \\
\text { Native Dutch } \\
(n=7772) \text { Immigrants } \\
(n=1305) \geq 18 \text { years }\end{array}$ & $\begin{array}{l}\text { To investigate ethnic- } \\
\text { related differences in } \\
\text { utilization in outpatient } \\
\text { mental health care }\end{array}$ & $\begin{array}{l}\text { Survey-based study } \\
\text { Dutch Second } \\
\text { National Survey of } \\
\text { General Practice } \\
\text { (A representative } \\
\text { sample of } 104 \mathrm{GP} \\
\text { practices) }\end{array}$ & $\begin{array}{l}\text { Contact with any } \\
\text { mental health service } \\
\text { during the last } 12 \\
\text { months }\end{array}$ & $\begin{array}{l}\text { Place of birth } \\
\text { (subject and } \\
\text { parents) } \\
\text { Surinamese, } \\
\text { Dutch, Antilleans, } \\
\text { Moroccans and } \\
\text { Turks }\end{array}$ & $\begin{array}{l}\text { Age \& gender } \\
\text { Self-reported } \\
\text { mental health }\end{array}$ & $\begin{array}{l}\text { Education level } \\
\text { Marital status } \\
\text { Proficiency in } \\
\text { Dutch language } \\
\text { Orientation towards } \\
\text { modern western } \\
\text { values Lay views } \\
\text { on illness and } \\
\text { treatment }\end{array}$ & $\begin{array}{l}\text { Migrant group's } \\
\text { utilization is about } \\
\text { half the level of } \\
\text { the native Dutch }\end{array}$ \\
\hline
\end{tabular}


Table 2 Descriptive summary of the studies included in the review (Continued)

\begin{tabular}{|c|c|c|c|c|c|c|c|c|c|c|}
\hline $\begin{array}{l}\text { Lee } \mathrm{CH} \\
\text { et al. [42] } \\
2013\end{array}$ & Singapore & 2008-2010 & $\begin{array}{l}374 \text { patients with } \\
\text { diagnosis of STEMI } \\
\text { Singapore-born } \\
\text { citizens }(n=286) \\
\text { Immigrants }(n=88)\end{array}$ & $\begin{array}{l}\text { To study disparities in } \\
\text { accessibility to high } \\
\text { quality health care, } \\
\text { and if patients' } \\
\text { psychosocial condition } \\
\text { after discharge was } \\
\text { associated with their } \\
\text { immigration status }\end{array}$ & $\begin{array}{l}\text { Survey-based study } \\
\text { Survey at university- } \\
\text { affiliated hospital in } \\
\text { Singapore }\end{array}$ & $\begin{array}{l}\text { Patients treated } \\
\text { with primary } \\
\text { percutaneous } \\
\text { coronary intervention, } \\
\text { median symptom-to- } \\
\text { balloon time, median } \\
\text { door-to-balloon time } \\
\text { and prescription of } \\
\text { evidence-based } \\
\text { medical therapy }\end{array}$ & $\begin{array}{l}\text { Place of birth and } \\
\text { citizenship (1) } \\
\text { Singapore-born } \\
\text { citizens (2) } \\
\text { Foreign-born } \\
\text { citizens (3) } \\
\text { Permanent } \\
\text { residents }\end{array}$ & $\begin{array}{l}\text { Cardiovascular } \\
\text { risk factor } \\
\text { profile } \\
\text { Admission } \\
\text { pathway }\end{array}$ & $\begin{array}{l}\text { Education level } \\
\text { Occupation Average } \\
\text { monthly household } \\
\text { income }\end{array}$ & $\begin{array}{l}\text { There were no } \\
\text { major disparities } \\
\text { in access to high } \\
\text { quality health care } \\
\text { for patients with } \\
\text { different immigration } \\
\text { status }\end{array}$ \\
\hline $\begin{array}{l}\text { Marchesini } \\
\text { G et al. [43] } \\
2014\end{array}$ & Italy & 2010 & $\begin{array}{l}7,856,348 \text { patients } \\
\text { Italy-born Italian } \\
\text { citizens ( } n=7,328,383) \\
\text { Foreign-born no Italian } \\
\text { citizens }(n=527,965) \\
\text { All ages }\end{array}$ & $\begin{array}{l}\text { To assess whether } \\
\text { prevalence, treatment } \\
\text { and direct costs of } \\
\text { drug-treated diabetes } \\
\text { were similar in } \\
\text { migrants and in } \\
\text { people of Italian } \\
\text { citizenship }\end{array}$ & $\begin{array}{l}\text { Register-based study } \\
\text { Administrative data } \\
\text { sources of all Italian } \\
\text { residents in } 30 \text { health } \\
\text { districts (ARNO } \\
\text { observatory) }\end{array}$ & $\begin{array}{l}\text { (1) Prescriptions } \\
\text { (2) Hospitalizations } \\
\text { (3) Healthcare } \\
\text { services (consultations, } \\
\text { laboratory tests and } \\
\text { other diagnostic } \\
\text { procedures) }\end{array}$ & Place of birth & Age \& gender & Place of residence & $\begin{array}{l}\text { Migrants show } \\
\text { a higher risk of } \\
\text { diabetes but less } \\
\text { intense treatment }\end{array}$ \\
\hline $\begin{array}{l}\text { Pourat N } \\
\text { et al. [44] } \\
2014\end{array}$ & $\begin{array}{l}\text { USA } \\
\text { (California) }\end{array}$ & 2009-2010 & $\begin{array}{l}59,938 \text { individuals } \\
\text { Natives }(n=8602) \\
\text { Immigrants }(n=388) \\
\text { All ages }\end{array}$ & $\begin{array}{l}\text { Test the validity of } \\
\text { the assertion that } \\
\text { undocumented } \\
\text { immigrants are more } \\
\text { frequent users of } \\
\text { health care }\end{array}$ & $\begin{array}{l}\text { Survey-based study } \\
\text { California Health } \\
\text { Interview Survey } \\
\text { (CHIS) }\end{array}$ & $\begin{array}{l}\text { (1) Number of } \\
\text { doctor visits in the } \\
\text { past year } \\
\text { (2) Percentage of } \\
\text { respondents with an } \\
\text { ED visits among } \\
\text { children and adults in } \\
\text { the past year (3) } \\
\text { Percentage of } \\
\text { children who had a } \\
\text { doctor visit in the } \\
\text { past year }\end{array}$ & $\begin{array}{l}\text { (1) US-born (2) } \\
\text { Naturalized citizen } \\
\text { (3) Legal } \\
\text { permanent } \\
\text { resident or other } \\
\text { authorized } \\
\text { immigration status } \\
\text { (4) Undocumented } \\
\text { immigrants }\end{array}$ & $\begin{array}{l}\text { Age \& gender } \\
\text { Ethnicity } \\
\text { Self-assessed } \\
\text { health status } \\
\text { Number of } \\
\text { chronic } \\
\text { conditions }\end{array}$ & $\begin{array}{l}\text { Insurance coverage } \\
\text { Official } \\
\text { Employment status } \\
\text { Household income } \\
\text { Family status } \\
\text { Family size } \\
\text { Language (English) } \\
\text { proficiency } \\
\text { Region of residence } \\
\text { Place of residence }\end{array}$ & $\begin{array}{l}\text { Utilization among } \\
\text { undocumented } \\
\text { immigrants } \\
\text { in all analyses was } \\
\text { lower than or } \\
\text { similar to that of } \\
\text { other groups }\end{array}$ \\
\hline
\end{tabular}


Table 2 Descriptive summary of the studies included in the review (Continued)

\begin{tabular}{|c|c|c|c|c|c|c|c|c|c|c|}
\hline $\begin{array}{l}\text { Ramos JM } \\
\text { et al. [28] } \\
2013\end{array}$ & $\begin{array}{l}\text { Spain } \\
\text { (Alicante) }\end{array}$ & 2011 & $\begin{array}{l}42,839 \text { individuals } \\
\text { Natives }(n=38,620) \\
\text { Immigrants }(n=4219) \\
\geq 15 \text { years }\end{array}$ & $\begin{array}{l}\text { To compare hospital } \\
\text { admission rates, } \\
\text { diagnoses at hospital } \\
\text { discharge, service of } \\
\text { admission at hospital } \\
\text { discharge, and mortality } \\
\text { between FCs and } \\
\text { autochthonous } \\
\text { citizens (ACs) }\end{array}$ & $\begin{array}{l}\text { Register-based study } \\
\text { Hospital discharges } \\
\text { registries from } \\
\text { hospital information } \\
\text { systems (Hospital } \\
\text { General Universitario } \\
\text { de Alicante (HGUA) } \\
\text { and Hospital } \\
\text { Universitario de } \\
\text { Sant Joan d'Alacant } \\
\text { (HUS)) }\end{array}$ & Hospital admissions & $\begin{array}{l}\text { Foreign citizen } \\
\text { (FC) } \\
\text { (people without } \\
\text { Spanish } \\
\text { citizenship) } \\
\text { (1) FCs from high } \\
\text { income countries } \\
\text { (born in } 25 \\
\text { European Union } \\
\text { countries, } \\
\text { Switzerland, } \\
\text { Iceland, Norway, } \\
\text { the USA, } \\
\text { Canada, Japan, } \\
\text { and Australia) } \\
\text { (2) FCs from low } \\
\text { income countries } \\
\text { (born elsewhere: } \\
\text { North Africa and } \\
\text { the Middle East, } \\
\text { Latin America, } \\
\text { Eastern Europe, } \\
\text { Sub-Saharan } \\
\text { Africa, and Asia) }\end{array}$ & $\begin{array}{l}\text { Age \& gender } \\
\text { Diagnosis at } \\
\text { discharge } \\
\text { Unit of } \\
\text { admission } \\
\text { Destination } \\
\text { at discharge } \\
\text { Length of } \\
\text { stay }\end{array}$ & - & $\begin{array}{l}\text { The utilization rate } \\
\text { was lower in } \\
\text { foreign citizens }\end{array}$ \\
\hline $\begin{array}{l}\text { Rucci P } \\
\text { et al. [18] } \\
2015\end{array}$ & $\begin{array}{l}\text { Italia } \\
\text { (Bologna) }\end{array}$ & 2010-2011 & $\begin{array}{l}8990 \text { individuals } \\
\text { Natives }(n=8602) \\
\text { Immigrants } \\
(n=388) \text { All ages }\end{array}$ & $\begin{array}{l}\text { To determine whether } \\
\text { disparities exist in } \\
\text { mental healthcare } \\
\text { provision to } \\
\text { immigrants and } \\
\text { natives with severe } \\
\text { mental illness }\end{array}$ & $\begin{array}{l}\text { Register-base study } \\
\text { Information system } \\
\text { of the Departments } \\
\text { of Mental Health } \\
\text { (DMH), Emilia- } \\
\text { Romagna }\end{array}$ & $\begin{array}{l}\text { (1) Receiving } \\
\text { psychosocial } \\
\text { rehabilitation the } \\
\text { following year (2) } \\
\text { Days admitted to } \\
\text { hospital wards or } \\
\text { to residential facilities } \\
\text { the following year }\end{array}$ & $\begin{array}{l}\text { Citizenship } \\
\text { (immigrants } \\
\text { comprise regular } \\
\text { immigrants, non- } \\
\text { documented } \\
\text { immigrants, } \\
\text { no Italian } \\
\text { citizenship) }\end{array}$ & $\begin{array}{l}\text { Age \& gender } \\
\text { Mental illness } \\
\text { diagnosis } \\
\text { Age at first } \\
\text { contact } \\
\text { Duration of } \\
\text { episode }\end{array}$ & $\begin{array}{l}\text { Education level } \\
\text { Marital status } \\
\text { Working status } \\
\text { Living arrangement } \\
\text { CMHC area }\end{array}$ & $\begin{array}{l}\text { Although the } \\
\text { probability of } \\
\text { receiving } \\
\text { any mental health } \\
\text { intervention is } \\
\text { similar between } \\
\text { immigrants and } \\
\text { Italians, the number } \\
\text { of interventions and } \\
\text { the duration of } \\
\text { admissions are } \\
\text { lower for immigrants } \\
\text { Immigrants spend } \\
\text { less days of } \\
\text { residential care } \\
\text { in licensed } \\
\text { psychiatric facilities } \\
\text { or other facilities }\end{array}$ \\
\hline
\end{tabular}


Table 2 Descriptive summary of the studies included in the review (Continued)

\begin{tabular}{|c|c|c|c|c|c|c|c|c|c|c|}
\hline $\begin{array}{l}\text { Smith- } \\
\text { Nielsen S } \\
\text { et al. [45] } \\
2015\end{array}$ & Denmark & $\begin{array}{l}\text { June- } \\
\text { August } \\
2007\end{array}$ & $\begin{array}{l}3,573 \text { individuals } \\
\text { Natives }(n=1131) \\
\text { Labour immigrants } \\
(n=808) \\
\text { RGE immigrants } \\
(n=1634) 18-64 \text { years }\end{array}$ & $\begin{array}{l}\text { To investigate whether } \\
\text { potential differences } \\
\text { exist in the use of } \\
\text { private practicing } \\
\text { psychiatrists and } \\
\text { psychologists }\end{array}$ & $\begin{array}{l}\text { Register and survey- } \\
\text { based study } \\
\text { Survey and registry } \\
\text { study on health and } \\
\text { health behaviour of } \\
\text { individuals registered } \\
\text { at the Danish Civil } \\
\text { Registration System } \\
\text { (CPR number) }\end{array}$ & $\begin{array}{l}\text { Use of psychiatrist } \\
\text { or psychologist } \\
\text { last year }\end{array}$ & $\begin{array}{l}\text { Citizenship: } \\
\text { (1) Ethnic Danes } \\
\text { (at least one } \\
\text { parent born in } \\
\text { Denmark with } \\
\text { Danish citizenship) } \\
\text { (2) Immigrant } \\
\text { (people residing } \\
\text { in Denmark } \\
\text { for a minimum } \\
\text { of } 3 \text { years and } \\
\text { born in a foreign } \\
\text { country to parents } \\
\text { without Danish } \\
\text { citizenship) } \\
\text { (RGC: Refugee } \\
\text { Generating } \\
\text { Countries: Turkey, } \\
\text { Pakistan, rraq, Iran, } \\
\text { Lebanon, Syria, } \\
\text { Somalia } \\
\text { and Yugoslavia) }\end{array}$ & $\begin{array}{l}\text { Age \& gender } \\
\text { Mental health } \\
\text { status } \\
\text { Physical health } \\
\text { symptoms }\end{array}$ & $\begin{array}{l}\text { Marital status } \\
\text { Education level } \\
\text { Employment status } \\
\text { Household income } \\
\text { Length of stay in } \\
\text { Denmark } \\
\text { Oral Danish } \\
\text { proficiency }\end{array}$ & $\begin{array}{l}\text { Immigrants from } \\
\text { RGC have similar } \\
\text { or higher use of } \\
\text { psychiatrists and } \\
\text { psychologists in } \\
\text { private practice } \\
\text { when taking mental } \\
\text { health into account } \\
\text { Labour immigrants } \\
\text { in general, except } \\
\text { for women using } \\
\text { psychiatrists, have } \\
\text { lower use of } \\
\text { psychiatrists and } \\
\text { psychologists }\end{array}$ \\
\hline $\begin{array}{l}\text { Spinogatti } \\
\text { F et al. [29] } \\
2015\end{array}$ & Italy & $2001-2010$ & $\begin{array}{l}139,775 \text { individuals } \\
>17 \text { years }\end{array}$ & $\begin{array}{l}\text { To analyse the } \\
\text { differences in mental } \\
\text { health service } \\
\text { utilization by immigrant } \\
\text { and native populations }\end{array}$ & $\begin{array}{l}\text { Register-base study } \\
\text { Regional mental } \\
\text { health information } \\
\text { system Departments } \\
\text { of Mental Health } \\
\text { (DHM), Lombardy }\end{array}$ & $\begin{array}{l}\text { (1) Contact with } \\
\text { psychiatric services } \\
\text { (2) Hospitalization } \\
\text { in acute psychiatric } \\
\text { wards }\end{array}$ & Country of birth & $\begin{array}{l}\text { Age \& gender } \\
\text { Mental disorder }\end{array}$ & $\begin{array}{l}\text { Marital status } \\
\text { Education level } \\
\text { Employment status }\end{array}$ & $\begin{array}{l}\text { The treated } \\
\text { prevalence of } \\
\text { native patients } \\
\text { outnumbers that } \\
\text { of immigrant ones, } \\
\text { although immigrant } \\
\text { patients use acute } \\
\text { mental health } \\
\text { services more } \\
\text { frequently }\end{array}$ \\
\hline $\begin{array}{l}\text { Straiton M } \\
\text { et al. [19] } \\
2014\end{array}$ & Norway & 2008 & $\begin{array}{l}2,712,974 \text { individuals } \\
\text { Natives }(n=2,604,757) \\
\text { Immigrants }(n=108,217) \\
18-67 \text { years }\end{array}$ & $\begin{array}{l}\text { To explore treatment } \\
\text { options in primary care } \\
\text { for immigrant women } \\
\text { with mental health } \\
\text { problems compared } \\
\text { with non-immigrant } \\
\text { women }\end{array}$ & $\begin{array}{l}\text { Register-base study } \\
\text { National registries } \\
\text { (1) National Population } \\
\text { Register (2) Norwegian } \\
\text { Health Economics } \\
\text { Administration } \\
\text { database-HELFO (3) } \\
\text { Norwegian Prescription } \\
\text { Database-NorPD }\end{array}$ & $\begin{array}{l}\text { PHC services (1) GP } \\
\text { psychological } \\
\text { consultations (2) } \\
\text { EPC psychological } \\
\text { consultation }\end{array}$ & $\begin{array}{l}\text { Country of birth } \\
\text { (1) Natives (born } \\
\text { in Norway with } \\
\text { both parents born } \\
\text { in Norway) } \\
\text { (2) Immigrants } \\
\text { (born abroad with } \\
\text { both parents from } \\
\text { abroad) staying at } \\
\text { least } 6 \text { months }\end{array}$ & $\begin{array}{l}\text { Age \& gender } \\
\text { GP and EPC } \\
\text { non- } \\
\text { psychological } \\
\text { consultation }\end{array}$ & $\begin{array}{l}\text { Marital status } \\
\text { Income level } \\
\text { Length of stay } \\
\text { Reason for migration } \\
\text { Place of residence }\end{array}$ & $\begin{array}{l}\text { Overall, immigrants } \\
\text { are less likely } \\
\text { to use a GP or } \\
\text { EPC services for } \\
\text { mental health } \\
\text { problems Immigrant } \\
\text { women are } \\
\text { somewhat } \\
\text { underrepresented in } \\
\text { PHC care services }\end{array}$ \\
\hline
\end{tabular}


Table 2 Descriptive summary of the studies included in the review (Continued)

\begin{tabular}{|c|c|c|c|c|c|c|c|c|c|c|}
\hline & & & & & & & & & & $\begin{array}{l}\text { for mental health } \\
\text { problems }\end{array}$ \\
\hline $\begin{array}{l}\text { Straiton ML } \\
\text { et al. [20] } \\
2016\end{array}$ & Norway & 2008 & $\begin{array}{l}1,283,437 \text { individuals } \\
\text { Natives }(n=1,230,175) \\
\text { Immigrants }(n=53,262) \\
20-67 \text { years }\end{array}$ & $\begin{array}{l}\text { (1) To identify in which } \\
\text { forms of treatment } \\
\text { immigrant women are } \\
\text { over or under } \\
\text { represented compared } \\
\text { with native Norwegians, } \\
\text { and if this varied by } \\
\text { country of origin } \\
\text { (2) To determine } \\
\text { whether use of an } \\
\text { interpreter increases } \\
\text { the likelihood of } \\
\text { accessing different } \\
\text { treatment types }\end{array}$ & $\begin{array}{l}\text { Register-base study } \\
\text { National registries (1) } \\
\text { National Population } \\
\text { Register (2) Norwegian } \\
\text { Health Economics } \\
\text { Administration } \\
\text { database-HELFO (3) } \\
\text { Norwegian Prescription } \\
\text { Database-NorPD }\end{array}$ & $\begin{array}{l}\text { Mental health } \\
\text { services (1) } \\
\text { Conversational } \\
\text { therapy (2) Psychiatric } \\
\text { referrals (3) } \\
\text { Psychotropic } \\
\text { medication (4) } \\
\text { Certificates for } \\
\text { sickness } \\
\text { leave and disability } \\
\text { applications }\end{array}$ & $\begin{array}{l}\text { Country of birth } \\
\text { (1) Natives (born } \\
\text { in Norway with } \\
\text { both parents born } \\
\text { in Norway) } \\
\text { (2) Immigrants } \\
\text { (born abroad with } \\
\text { both parents from } \\
\text { abroad) staying at } \\
\text { least } 6 \text { months, } \\
\text { divided according } \\
\text { to the World Bank } \\
\text { income categories } \\
\text { of their country } \\
\text { of origin }\end{array}$ & $\begin{array}{l}\text { Age } \\
\text { Diagnosis } \\
\text { Use of } \\
\text { interpreter }\end{array}$ & $\begin{array}{l}\text { Marital status } \\
\text { Income level } \\
\text { Length of stay } \\
\text { Place of residence }\end{array}$ & $\begin{array}{l}\text { Women are } \\
\text { somewhat } \\
\text { underrepresented } \\
\text { in PHC services } \\
\text { for mental health } \\
\text { problems A higher } \\
\text { percentage of } \\
\text { Norwegian } \\
\text { women had had a } \\
\text { Psychiatric } \\
\text { consultation than } \\
\text { any of the } 6 \\
\text { immigrant groups } \\
\text { Psychiatric referral } \\
\text { rates did not differ } \\
\text { by country of origin }\end{array}$ \\
\hline $\begin{array}{l}\text { Tarraf W } \\
\text { et al. [30] } \\
2014\end{array}$ & USA & $2000-2008$ & $\begin{array}{l}167,889 \text { individuals } \\
\text { US-born }(n=133,102) \\
\text { Naturalized FB-citizens } \\
(n=14,338) \text { Non-citizens } \\
(n=20,449) \geq 18 \text { years }\end{array}$ & $\begin{array}{l}\text { (1) Provide a detailed } \\
\text { accounting of ED use } \\
\text { with policy-relevant } \\
\text { immigrant } \\
\text { Classifications (2) } \\
\text { Examine associations } \\
\text { between ED use and } \\
\text { citizenship status } \\
\text { using a Behavioural } \\
\text { Model of healthcare } \\
\text { access and utilization } \\
\text { (3) Determine the } \\
\text { most important factors } \\
\text { associated with } \\
\text { differences in } \\
\text { immigrants' ED } \\
\text { services use }\end{array}$ & $\begin{array}{l}\text { Survey-based study } \\
\text { (1) Medical } \\
\text { Expenditures } \\
\text { Panel Survey (MEPS) } \\
\text { (2) National Health } \\
\text { Interview Survey }\end{array}$ & $\begin{array}{l}\text { Self-reported } \\
\text { past-year } \\
\text { ED use }\end{array}$ & $\begin{array}{l}\text { Immigration status } \\
\text { and place of birth } \\
\text { (1) US-born citizens } \\
\text { (2) Naturalized } \\
\text { foreign-born (FB) } \\
\text { citizens (immigrants } \\
\text { who have obtained } \\
\text { US citizenship) } \\
\text { (3) FB non-citizens } \\
\text { (legal permanent } \\
\text { residents, as well as } \\
\text { undocumented } \\
\text { and "other" } \\
\text { immigrants) }\end{array}$ & $\begin{array}{l}\text { Age \& gender } \\
\text { Self-reported } \\
\text { ethnicity/race } \\
\text { Self-rated } \\
\text { health } \\
\text { Medical } \\
\text { conditions } \\
\text { Past-year } \\
\text { healthcare } \\
\text { provider visits } \\
\text { Past-year } \\
\text { hospital } \\
\text { discharges }\end{array}$ & $\begin{array}{l}\text { Insurance status } \\
\text { Usual source } \\
\text { of care availability } \\
\text { Education level } \\
\text { Household } \\
\text { income-to-poverty } \\
\text { Place of residence } \\
\text { (urbanity) Region }\end{array}$ & $\begin{array}{l}\text { Immigrants, and } \\
\text { particularly } \\
\text { non-citizens, } \\
\text { were less likely to } \\
\text { use ED services } \\
\text { Non-citizens are } \\
\text { less likely to use } \\
\text { ED services and } \\
\text { showed that they } \\
\text { are also less likely } \\
\text { to be repeat users }\end{array}$ \\
\hline
\end{tabular}


Table 2 Descriptive summary of the studies included in the review (Continued)

\begin{tabular}{|c|c|c|c|c|c|c|c|c|c|c|}
\hline $\begin{array}{l}\text { Tormo MJ } \\
\text { et al. [31] } \\
2015\end{array}$ & $\begin{array}{l}\text { Spain } \\
\text { (Murcia) }\end{array}$ & 2006-2008 & $\begin{array}{l}2453 \text { individuals } \\
\text { Natives }(n=1303) \\
\text { Immigrants }(n=1303) \\
18-64 \text { years }\end{array}$ & $\begin{array}{l}\text { To describe the } \\
\text { utilization of health } \\
\text { services among } \\
\text { immigrant and male } \\
\text { and female native } \\
\text { populations }\end{array}$ & $\begin{array}{l}\text { Survey-based study } \\
\text { (1) Spanish National } \\
\text { Health Survey (SNHS) } \\
\text { (2) Health and Culture } \\
\text { Survey (SyC) }\end{array}$ & $\begin{array}{l}\text { (1) Unmet healthcare } \\
\text { need in the last } \\
12 \text { months (2) Visit } \\
\text { to a GP in the last } \\
\text { year (3) Visit to } \\
\text { dentist in the last } \\
\text { year (4) Hospitalization } \\
\text { and ED visit in the } \\
\text { past year (5) Drug } \\
\text { consumption it } \\
\text { last } 2 \text { weeks }\end{array}$ & $\begin{array}{l}\text { Immigrants with } \\
\text { Health Insurance } \\
\text { Card (Tarjeta } \\
\text { Sanitaria } \\
\text { Individual-TSI) }\end{array}$ & $\begin{array}{l}\text { Age \& gender } \\
\text { Self-assessed } \\
\text { health status } \\
\text { Health } \\
\text { problems } \\
\text { last year } \\
\text { Activity } \\
\text { limitation } \\
\text { last } 2 \text { weeks }\end{array}$ & $\begin{array}{l}\text { Education level } \\
\text { Social class }\end{array}$ & $\begin{array}{l}\text { Migrants showed } \\
\text { a lower use of } \\
\text { PHC services } \\
\text { specialists, } \\
\text { but a higher use } \\
\text { of ED }\end{array}$ \\
\hline $\begin{array}{l}\text { Verhagen I } \\
\text { et al. [32] } \\
2014\end{array}$ & Netherlands & 2010 & $\begin{array}{l}68,214 \text { individuals } \\
\text { Natives }(n=33,725) \\
\text { Immigrants }(n=34,489) \\
\geq 55 \text { years }\end{array}$ & $\begin{array}{l}\text { To study whether } \\
\text { healthcare use of the } \\
\text { four ethnic minority } \\
\text { elderly populations in } \\
\text { the Netherlands varies } \\
\text { from the ethnic Dutch } \\
\text { elderly }\end{array}$ & $\begin{array}{l}\text { Register-base study } \\
\text { Registry data from } \\
\text { the Achmea Health } \\
\text { Insurance Company } \\
\text { (Achmea) }\end{array}$ & $\begin{array}{l}\text { (1) GP services (2) } \\
\text { Receipt of } \\
\text { prescriptions (3) } \\
\text { Physical therapy (4) } \\
\text { Hospital services (5) } \\
\text { Medical aids to help } \\
\text { with a limitation }\end{array}$ & $\begin{array}{l}\text { Country of birth } \\
\text { or surname } \\
\text { Turkish, Moroccan, } \\
\text { Surinamese } \\
\text { and Moluccan }\end{array}$ & Age \& gender & $\begin{array}{l}\text { Additional health } \\
\text { insurance } \\
\text { Neighbourhood } \\
\text { deprived }\end{array}$ & $\begin{array}{l}\text { The use of PHC } \\
\text { failities (GP services } \\
\text { and prescriptions) } \\
\text { within most ethnic } \\
\text { minority groups is } \\
\text { higher; however, } \\
\text { they generally } \\
\text { make less use of } \\
\text { hospital care, } \\
\text { medical aids, and } \\
\text { physical therapy }\end{array}$ \\
\hline $\begin{array}{l}\text { Villarroel N } \\
\text { et al. [46] } \\
2015\end{array}$ & Spain & 2006 & $\begin{array}{l}22,224 \text { patients Natives } \\
(n=20,226) \text { Immigrants } \\
(n=1998) 16-64 \text { years }\end{array}$ & $\begin{array}{l}\text { (1) To analyse } \\
\text { differences in patterns } \\
\text { of healthcare use } \\
\text { (visits to } P C \text {, } \\
\text { hospitalizations and } \\
\text { emergency visits) } \\
\text { between the native } \\
\text { Spanish population } \\
\text { and immigrants } \\
\text { from the seven leading } \\
\text { countries in terms of } \\
\text { number of immigrants }\end{array}$ & $\begin{array}{l}\text { Survey-based study } \\
\text { Spanish National } \\
\text { Health Survey (SNHS) } \\
\text { 2006-2007 }\end{array}$ & $\begin{array}{l}\text { (1) Visit to a GP in the } \\
4 \text { weeks before (2) } \\
\text { Hospitalization in the } \\
\text { past year (3) ED visits } \\
\text { in the past year }\end{array}$ & Country of birth & $\begin{array}{l}\text { Age \& gender } \\
\text { Self-perceived } \\
\text { health status }\end{array}$ & $\begin{array}{l}\text { Marital status } \\
\text { Educational level } \\
\text { Employment status } \\
\text { Social support } \\
\text { (adapted from the } \\
\text { Duke-UNC } \\
\text { Functional Social } \\
\text { Support } \\
\text { Questionnaire) } \\
\text { Social support } \\
\text { (adapted from the } \\
\text { Duke-UNC }\end{array}$ & $\begin{array}{l}\text { Immigrants made } \\
\text { less than, or } \\
\text { about the same } \\
\text { use of healthcare } \\
\text { services Among } \\
\text { men, a lower use } \\
\text { of healthcare } \\
\text { services was found } \\
\text { among } \\
\text { those born in } \\
\text { Romania for all } \\
\text { healthcare levels }\end{array}$ \\
\hline
\end{tabular}


Table 2 Descriptive summary of the studies included in the review (Continued)

\begin{tabular}{|c|c|c|c|c|c|c|c|c|c|c|}
\hline & & & & $\begin{array}{l}\text { in Spain in } 2006 \text { (2) To } \\
\text { examine whether the } \\
\text { differences are explained } \\
\text { by self-perceived health } \\
\text { status, educational level, } \\
\text { family characteristics, } \\
\text { employment status and } \\
\text { social support (3) To } \\
\text { determine whether the } \\
\text { patterns of association } \\
\text { differ by gender }\end{array}$ & & & & & $\begin{array}{l}\text { Functional Social } \\
\text { Support } \\
\text { Questionnaire) }\end{array}$ & $\begin{array}{l}\text { and among } \\
\text { Ecuadorians for } \\
\text { hospitalizations } \\
\text { Among women } \\
\text { a lower use of } \\
\text { PHC was found } \\
\text { among those born } \\
\text { in Argentina, Bolivia } \\
\text { and Ecuador, and a } \\
\text { higher use among } \\
\text { Peruvians. No } \\
\text { differences were } \\
\text { observed with } \\
\text { native-born subjects } \\
\text { A higher utilization } \\
\text { of healthcare } \\
\text { services was } \\
\text { only found among } \\
\text { men born in Bolivia, } \\
\text { who were more } \\
\text { likely to use } \\
\text { hospitalization }\end{array}$ \\
\hline $\begin{array}{l}\text { Wang L } \\
{[47]} \\
2014\end{array}$ & Canada & $2005-2010$ & $\begin{array}{l}94,948 \text { individuals } \\
\text { Canadian-born }(n= \\
73,806) \text { Foreign born } \\
(n=21,142) 18-75 \text { years }\end{array}$ & $\begin{array}{l}\text { Explore the relationships } \\
\text { among individual } \\
\text { socio-economic status, } \\
\text { residential } \\
\text { neighbourhood } \\
\text { characteristics and } \\
\text { self-reported health for } \\
\text { multiple immigrant } \\
\text { groups }\end{array}$ & $\begin{array}{l}\text { Survey-based study } \\
\text { Canadian Community } \\
\text { Health Survey (CCHS) }\end{array}$ & $\begin{array}{l}\text { (1) Have a regular } \\
\text { physician (2) Stay } \\
\text { overnight in hospital } \\
\text { (3) Number of } \\
\text { dental visits per year } \\
\text { (4) Number of } \\
\text { physician visits per } \\
\text { year }\end{array}$ & $\begin{array}{l}\text { Country of birth, } \\
\text { ethnic origin and } \\
\text { immigrant status } \\
\text { (1) Native born (2) } \\
\text { Long-standing } \\
\text { groups (Italian and } \\
\text { Portuguese) } \\
\text { (3) Recent groups } \\
\text { (Chinese and } \\
\text { South Asian) (4) } \\
\text { Overall foreign } \\
\text { born }\end{array}$ & $\begin{array}{l}\text { Age \& gender } \\
\text { Self-perceived } \\
\text { health status } \\
\text { Chronic } \\
\text { diseases Health } \\
\text { behaviour } \\
\text { (smoke, } \\
\text { overweight, } \\
\text { physical } \\
\text { activity, } \\
\text { vegetable } \\
\text { intake) }\end{array}$ & $\begin{array}{l}\text { Marital status } \\
\text { Education level } \\
\text { Household } \\
\text { income } \\
\text { Language } \\
\text { proficiency } \\
\text { Length of stay } \\
\text { Neighbourhood } \\
\text { characteristics } \\
\text { (deprivation \& } \\
\text { ethic } \\
\text { concentration) }\end{array}$ & $\begin{array}{l}\text { Immigrants have } \\
\text { lower rates of } \\
\text { overnight stay } \\
\text { in hospital } \\
\text { All four selected } \\
\text { immigrant groups } \\
\text { have higher rates } \\
\text { for having a } \\
\text { regular physician } \\
\text { Immigrants } \\
\text { report significantly } \\
\text { more physician } \\
\text { visits Foreign-born } \\
\text { groups report } \\
\text { fewer dental visits }\end{array}$ \\
\hline
\end{tabular}


Table 2 Descriptive summary of the studies included in the review (Continued)

\begin{tabular}{|c|c|c|c|c|c|c|c|c|c|c|}
\hline $\begin{array}{l}\text { Wang L } \\
\text { et al. [48] } \\
2015\end{array}$ & Canada & $2005-2010$ & $\begin{array}{l}161,981 \text { individuals } \\
\text { Native born } \\
(n=124,946) \text { Korean } \\
\text { immigrants }(n=351) \\
\text { Overall foreign born } \\
(n=36,684) \geq 25 \text { years }\end{array}$ & $\begin{array}{l}\text { To explore healthcare- } \\
\text { seeking behaviour of } \\
\text { South Korean } \\
\text { immigrants in Toronto, } \\
\text { Canada, and how } \\
\text { transnationalism shapes } \\
\text { post-migration health } \\
\text { and health- } \\
\text { management strategies }\end{array}$ & $\begin{array}{l}\text { Survey-based study } \\
\text { Canadian Community } \\
\text { Health Survey (CCHS) } \\
\text { 2005-2010 }\end{array}$ & $\begin{array}{l}\text { (1) Stay overnight in } \\
\text { hospital (2) Physician } \\
\text { visits (3) Dental visits }\end{array}$ & $\begin{array}{l}\text { Country of birth } \\
\text { (1) Native born in } \\
\text { Canada (2) Overall } \\
\text { foreign born } \\
\text { (3) Korean } \\
\text { immigrant }\end{array}$ & $\begin{array}{l}\text { Age \& gender } \\
\text { Self-perceived } \\
\text { health status } \\
\text { Chronic } \\
\text { diseases }\end{array}$ & $\begin{array}{l}\text { Marital status } \\
\text { Education level } \\
\text { Employment status } \\
\text { Household income } \\
\text { Immigration category } \\
\text { Length of stay } \\
\text { Place of residence }\end{array}$ & $\begin{array}{l}\text { Of the three } \\
\text { groups, Koreans } \\
\text { use health services } \\
\text { the least } \\
\text { They have the } \\
\text { lowest rate of } \\
\text { having a regular } \\
\text { doctor and } \\
\text { overnight stay in } \\
\text { hospital, the } \\
\text { lowest numbers } \\
\text { for dental and } \\
\text { physician visits } \\
\text { in the past } 12 \\
\text { months, and the } \\
\text { highest rate of no } \\
\text { doctor visit in the } \\
\text { past } 12 \text { months }\end{array}$ \\
\hline
\end{tabular}

CMHC Community Mental Health Centers, ED emergency department, EPC emergency primary care, GP general practitioner, HIC high income country, LIC low income country, MIC medium income country, OHIP Ontario Health Insurance Plan, PHC primary health care, STMI ST segment elevation myocardial infarction 
same dataset [13-16, 19, 20, 25, 47, 48]. Nevertheless, as these articles focused on different aspects of healthcare use or outcome measures, all were included in this review.

Distribution of studies regarding publication year was as follows: 8 studies published in 2013 [17, 22-24, 27, 28, 41, 42], 15 in 2014 [14-16, 19, 21, 30, 32, 33, 35, 36, 38, 40, 43, 44, 47], 10 in 2015 [13, 18, 25, 26, 29, 31, 34, 45, 46, 48] and 3 in 2016 [20, 37, 39]. The majority of the publications analysed data from European countries (28; 78\%), both North and Central (12) (Norway [13-15, 19, 20], Denmark [45], Sweden [35], the Netherlands $[17,32,34,40]$ and Austria [41]) and South Europe (15) (France [22, 36], Italy [18, 24, 29, $37,43]$, Spain [23, 27, 28, 31, 38, 39, 46] and Portugal [33]) and 1 from the UK [26]. Seven papers (19\%) explored this issue in North America (2 from USA [30, 34] and 5 from Canada [16, 21, 25, 47, 48]); and 1 (3\%) in Asia (Singapore) [42] (see Fig. 2).

Geographical coverage of the studies has some variation: 21 performed at the national level $[13-15,17,19-22,28,30,32,34-36,38,40,41,45-48], 10$ at a regional level $[16,18,23,25-27,29,31,37,44], 3$ at a local level $[28,33,42]$ and 1 multi-country study [39] with data from a regional level of 1 country and the national level of the other. There were only 4 longitudinal studies (2 prospective [18, 42] and 2 retrospective $[27,43]$ ) and 1 case-control study [35]. Sample sizes ranged from 74 [35] to 7,856,348 [43]. Multivariable regression (Poisson or logistic) was the most frequent analysis. Only 9 studies conducted univariate analysis $[29,32,33,35,38,43,48]$.

\section{Sources of information}

Service utilization could be assessed from two perspectives: the physician's perspective, based on recorded databases and volume of medical services, and the patient's perspective, based on patient-reported use of services through healthcare surveys [49].

The largest number of papers (18) used information from administrative [13-16, 18-20, $23,25,29,33,35,37,39,43]$ or insurance system databases [32, 34] and specific hospital

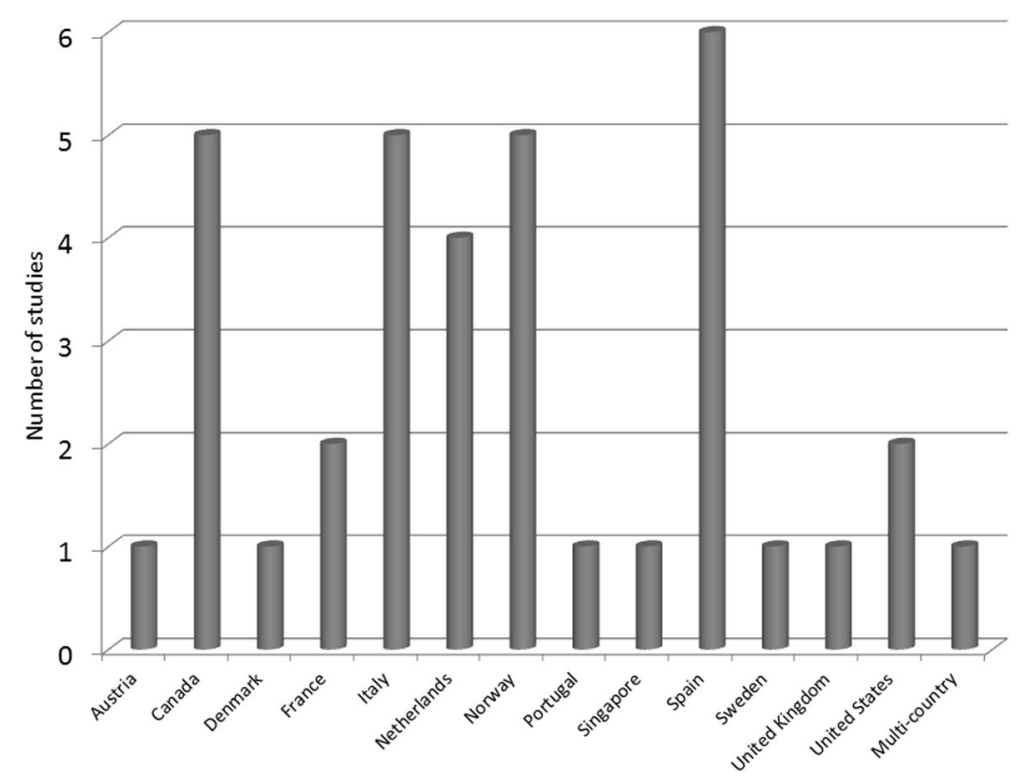

Fig. 2 Distribution of studies according to country of destination 
registries [28] as source of information. Among the 16 papers (44.4\%) that analysed healthcare surveys, where people report their individual healthcare use, 14 studies used population-based surveys which were elaborated for other purposes [17, 21, 22, 24, 26, 30, $36,38,40,44,46-48]$ while 3 of the surveys were specifically designed to explore immigrants healthcare use [31, 41, 42]. Only 2 studies [33, 45] (5.6\%) combined health survey and administrative information and 1 study also used a national survey for general practitioners (GPs) [17].

\section{Subjects}

There were diverse definitions of immigrants. Country of birth was the most common criteria used to define immigrants (18), or country of birth of the subject and their parents (10). In addition, name recognition (2) [32, 34], citizenship (3) [18, 24, 28] or a combination of citizenship and country of birth (3) [30,42,45] were also used.

The majority of papers classified the immigrant population in sub-groups usually based on country of birth (13). However, some studies considered geographic area of origin (8) or World Bank categories of income level (5). Other less frequent categories considered were legal status (3), reason of migration (1), length of stay in the country (3) and being first of second generation (1). Only 2 studies $(5.6 \%)[18,22]$ compared the use of services considering the immigrant populations as a whole, without defining specific sub-groups in those populations.

\section{Findings}

The outcome "healthcare service utilization" could be organized in seven focus areas: primary care, specialist's services, hospitalizations, emergency services, mental health, dental care and medication prescription. Some studies reported on more than one outcome. In total, 8 papers analysed the use of primary care (including GP visits, dental care and physiotherapy) [13-15, 21, 27, 36, 44, 48], 6 evaluated the use of specialist services (including hospitalizations or emergency care) [23, 28, 30, 33, 35, 42], 5 assessed mental health services $[17,18,20,29,45], 10$ evaluated the use of both primary care and specialists [22, 24, 31, 32, 34, 37, 38, 43, 46, 47], 2 evaluated primary care and mental health $[19,40], 4$ evaluated both primary care, mental health and hospitalizations [16, 25, 26, 41] and 1 studied pharmaceutical use and prescriptions [39]. In addition, 6 studies also reported medication consumption [20,31, 32, 37, 42, 43].

The measurement of healthcare utilization was either continuous (number of contacts) or dichotomic (having had any contact). The period of time used to determine utilization ranged from 4 weeks through 1 year.

The more frequent outcome was that immigrants have lower [17-20, 22, 25, 27, 28, $30,33,35,40,43,44,48]$ or similar $[13,21,34,36,41,42]$ healthcare utilization. However, studies that included analysis by sub-groups of immigrants identified some differences across groups $[14-16,23,26,31,37,39,40,45,46]$ as well as with the type of service assessed [14, 24, 29, 31, 32, 38, 40, 46, 47].

The immigrant population showed a similar $[23,24,29,31,32,34,36-40,46]$ or lower $[17,18,22,27,28,33,43]$ use of primary care and specialized care in countries with universal access to health care-even for undocumented migrants [50]. This finding was consistent regardless of the source of information used. In other countries, 
some differences were identified associated with the source of information: immigrants showed higher use of health services when estimates were based on surveys [26, 41, 45], while their rates were lower $[19,20,35]$ or similar [13-15] when registries or administrative data were used.

\section{Discussion}

The main result of this review is that migrant populations appear to have a lower use of health services than native populations, with a similar level of use of primary care services. This result appears to be independent from differences in need of access. Nevertheless, the great heterogeneity of the studies included in this review, considering both the sources of information, as well as factors used for controlling health need and to classify immigrants in sub-groups, requires caution when making an overall estimation valid for all immigrants.

Different sources of heterogeneity should be mentioned. First, and probably the factor with the highest relevance, was the definition of immigrant and their characterization. This review has identified several factors that could be involved with differences in healthcare utilization among immigrants: income of the original native countries [13-15, 28, 38], the specific reasons motivating migration $[15,16,19,25,26]$, fluency in the host country language $[16,17,21,25,44,45,47]$ and length of time of stay [13, 15, 19-21, 26, 38, 45, 47, 48].

There were also differences in how medical need was determined and how to estimate factors that predispose to healthcare use. The majority of studies assessed health needs from the point of view of self-perceived health, and through commonly used socio-demographic variables, such as education, income or working status, following the model of Aday and Anderson [51, 52]. Multivariable models were adjusted by these variables to eliminate the effect they could have on utilization, but whether they had a differential influence on immigrants or native populations remains inconclusive.

Variables which could have a significant effect on healthcare service use and in particular for mental health care [53], such as health beliefs and cultural concepts on the part of the immigrants, fear of stigmatization, taboos, perceived efficacy of health interventions or use of alternative services, were usually not considered. The effect of these variables is most commonly explored through qualitative techniques, and papers that used those methods were not included in this report.

Variation in countries' healthcare systems limits direct cross-country comparisons, although immigrants showed similar patterns of utilization in countries with significant differences in their healthcare services. Nevertheless, studies reviewed pay little attention to the structural and organizational dimensions of healthcare systems, other than reporting the specific conditions for accessing health services. One paper explored the influence of attitudes of professionals regarding immigrants [54], 2 studies assessed the reasons for unmet healthcare need $[31,38]$ while 2 underscored the patient workload of healthcare professionals [22, 23]. In addition, the effect that new legislation enacted in different countries could have had on access to healthcare services by immigrants has not yet been evaluated and published and therefore cannot be assessed in this review.

Attempting to expanding the scope of previous reviews, we tried not to constrain the inclusion criteria regarding areas of healthcare services assessed $[10,55,56]$, context of the study (country) $[54,55]$, or characteristics of immigrants $[54,55]$.

This work adds also new information regarding the use of mental health services, both in terms of primary $[19,26]$ and specialized mental services $[16-18,20,25,29,41,45]$. 
Nevertheless, and although immigrants have shown a higher susceptibility to emotional and mental health problems that could be linked to the stressors of adapting to the host country [57], those studies reported similar findings as for other health services: an overall lower use by migrants, also with differences across sub-groups and with an occasional higher use of emergency care.

This review also provides the opportunity to have an insight of the healthcare use of certain vulnerable sub-groups, as the handicapped [13], the elderly [13, 15, 32, 37] or patients with chronic conditions [21,34,36], but the pattern of use of those sub-groups is similar to that of the general population, even when immigrants seem to have less health problems than natives [13,34], or a poorer health status [36]. Immigrants also showed a higher use associated with longer periods of stay in the host countries $[15,21]$ as well as significant differences of use among migrant sub-groups [32, 37].

The effect of gender differences was assessed most notably in papers evaluating the use of mental health services [16, 19, 20, 25, 41, 45]. Nevertheless, no conclusive evidence could be established: compared to their native counterparts, Straiton et al [19, 20] and Durbin et al $[16,25]$ found a lower use of mental health services for immigrant women, while Kerkenaar et al [41] and Smith-Nielsen et al. [45] found a higher use.

The possibility to analyse the use of different levels of care may help to determine the existence of gaps in utilization (less use in one area could explain an increased use in another area) or highlight the existence of different referral criteria (primary care specialists) [23]. De Luca et al. found [24] an over-utilization of emergency services associated with an under-utilization of preventive care services among the immigrant population. Tormo et al. [31] and Díaz et al. [14] obtained similar results, although they concluded that the higher use of emergency services did not compensate the lower use of GPs. The identification of differences in pharmaceutical consumption could also lead to identify particular health problems or economic barriers accentuated by the development of restrictive health policies.

Lastly, the large number of European studies, particularly from western and central Europe, has to be highlighted, probably depicting the interest about the migratory pressure these countries have faced in the last years-migration from Eastern Europe after the fall of the Iron Curtain; from Latin America, North and sub-Saharan Africa; from internal migration flows south-north after the economic crisis; or most recently, the refugee crisis.

\section{Study limitations}

The literature search was conducted only in one database (MEDLINE), although the electronic search was manually completed using Google Scholar. There were implied limitations in the manual search, since it was not systematized and was susceptible to errors as it relied on title appropriateness (particularly for articles with ambiguous titles). Furthermore, no backward citation of the papers included in the systematic review was performed. Additionally, the systematic search only identified $50 \%$ of the papers accepted for inclusion, which raises some doubts regarding the intrinsic limitations of the system to classify and assign terms to papers that compare the use of healthcare services between native and migrants.

Finally, qualitative papers that explored the use of healthcare services were not included, as it would be difficult to draw comparisons from these studies. 


\section{Conclusions}

Overall, and regardless of the changes in the immigration process, data here analysed is coincident with results obtained in previous reviews [10,54,56], confirming that immigrants show a general tendency to a lower use of health services than native populations. But these data also indicate the existence of differences within the immigrant populations, reinforcing the conclusion that further studies intended to compare the rate of healthcare use between native and immigrant populations should incorporate information that allows for better identification and characterization of the immigrant population. The immigrant population cannot be considered as a uniform whole. Their diversity has to be taking into account when describing and analysing their healthcare utilization. This will also require improvement and standardization of the information collected [55, 58].

In this sense, the limitations of health surveys have to be emphasized. Surveys are not just subjected to memory bias, but they are less suited to be representative of all relevant sub-groups of the immigrant population, as their samples usually do not include enough participants to reflect the wide variability of the diverse immigrant population to estimate their differential use. For instance, only one paper includes immigrants in irregular status [44]. Therefore, the use of data that overcome these limitations has to be encouraged. Further studies should be based on other information, such as registers, administrative or insurance data, or data from non-governmental organizations [59].

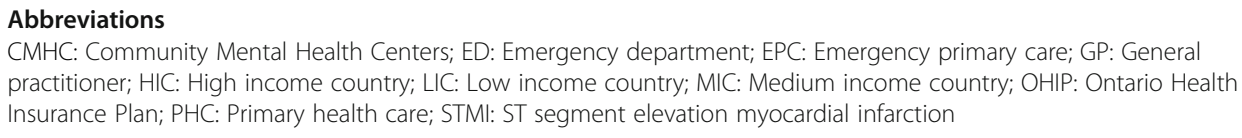

Availability of data and materials

Not applicable.

\section{Authors' contributions}

ASS was the principal investigator who contributed to the conception and design of the study; collected, entered, analysed and interpreted the data; led the paper and acted as corresponding author. AlHG collected, entered, analysed and interpreted the data and prepared the manuscript. LAGF contributed to data analysis and interpretation and drafted the manuscript, and RC participated in the conception and design of the study and helped to draft the paper. All authors read and approved the final manuscript.

Competing interests

The authors declare that they have no competing interests.

Consent for publication

Not applicable.

Ethics approval and consent to participate

Not applicable.

\section{Author details}

${ }^{1}$ Red de Investigación en Servicios de Salud y Enfermedades Crónicas, Madrid, Spain. ${ }^{2}$ National School of Public Health, Institute of Health Carlos III, Madrid, Spain. ${ }^{3}$ IMIENS, UNED, Madrid, Spain. ${ }^{4}$ Faculty of Medicine, University of Alcalá, Alcalá, Spain. ${ }^{5}$ University Hospital Fundación Alcorcón, Alcorcón, Spain. ${ }^{6}$ Agency for Health Technology Assessment, Institute of Health Carlos III, Madrid, Spain. ${ }^{7}$ EpiChron Research Group on Chronic Diseases, Aragon Health Sciences Institute (IACS), IIS Aragón, Zaragoza, Spain. ${ }^{8}$ San Pablo Health Centre, Aragonese Health Service, Zaragoza, Spain. ${ }^{9}$ Department of Medicine, Psychiatry and Dermatology, University of Zaragoza, Zaragoza, Spain. 
References

1. United Nations, Department of Economic and Social Affairs, Population Division. International Migration Report 2015: Highlights (ST/ESA/SER.A/375). 2016. http://www.un.org/en/development/desa/population/migration/ publications/migrationreport/docs/MigrationReport2015_Highlights.pdf. Accessed 22 Jul 2016

2. United Nations, Department of Economic and Social Affairs, Population Division (2013). International Migration Report 2013. 2013. http://www.un.org/en/development/desa/population/publications/migration/migration-report2013.shtml. Accessed: 22 Jul 2016.

3. Rechel B, Mladovsky P, Ingleby D, Mackenbach JP, McKee M. Migration and health in an increasingly diverse Europe. Lancet. 2013;381:1235-45.

4. Hemminki K. Immigrant health, our health. Eur J Public Health. 2014;24:92-5.

5. Real Decreto-ley $16 / 2012$, de 20 de abril, de medidas urgentes para garantizar la sostenibilidad del Sistema Nacional de Salud y mejorar la calidad y seguridad de sus prestaciones. Madrid: Agencia Estatal Boletín Oficial del Estado (April 20, 2012). https://www.boe.es/diario_boe/txt.php?id=BOE-A-2012-5403. Accessed 9 Mar 2016 [Article in Spanish]

6. Immigration Act 2014 c.22. UK Parliament. London: The Stationery Office (May 14, 2014). http://www.legislation. gov.uk/ukpga/2014/22/contents/enacted. Accessed 10 Oct 2016.

7. Public Law 111-148. Patient Protection and Affordable Care Act. 111th United States Congress. Washington, D.C.: United States Government Printing Office (March 23, 2010). https://www.gpo.gov/fdsys/granule/PLAW111 publ148/PLAW-111 publ148/content-detail.html. Accessed 10 Oct 2016.

8. Villalonga-Olives E, Kawachi I. The changing health status of economic migrants to the European Union in the aftermath of the economic crisis. J Epidemiol Community Health. 2014;68:801-3.

9. Ronda-Pérez E, Ortiz-Barreda G, Hernando C, Vives-Cases C, Gil-González D, Casabona G. Características generales de los artículos originales incluidos en las revisiones bibliográficas sobre salud e inmigración en España. Rev Esp Salud Publica. 2014;88:675-85 [Article in Spanish]

10. Carmona R, Alcazar-Alcazar R, Sarria-Santamera A, Regidor E. Frecuentación de las consultas de medicina general y especializada por población inmigrante y autóctona: una revisión sistemática. Rev Esp Salud Publica. 2014;88:13555 [Article in Spanish].

11. Béland F. Utilization of health services as events: an exploratory study. Health Serv Res. 1988;23.

12. European Commission. EU Immigration portal. Glossary. 2016. http://ec.europa.eu/immigration/glossary_en. Accessed: 22 Jul 2016.

13. Diaz E, Kumar BN, Engedal K. Immigrant patients with dementia and memory impairment in primary health care in Norway: a national registry study. Dement Geriatr Cogn Disord. 2015;39:321-31.

14. Díaz E, Calderón-Larran A, Prado-Torres A, Poblador-Plou B, Gimeno-Feliú LA. How do immigrants use primary health care services? A register-based study in Norway. Eur J Public Health. 2015;25:72-8.

15. Diaz E, Kumar BN. Differential utilization of primary health care services among older immigrants and Norwegians: a register-based comparative study in Norway. BMC Health Serv Res. 2014;14:623.

16. Durbin A, Lin E, Moineddin R, Steele LS, Glazier RH. Use of mental health care for nonpsychotic conditions by immigrants in different admission classes and by refugees in Ontario, Canada. Open Med. 2014:8:e136-46.

17. Koopmans GT, Uiters E, Deville W, Foets M. The use of outpatient mental health care services of migrants vis-à-vis Dutch natives: Equal access? Int J Soc Psychiatry. 2013;59:342-50.

18. Rucci P, Piazza A, Perrone E, Tarricone I, Maisto R, Donegati I, et al. Disparities in mental health care provision to immigrants with severe mental illness in Italy. Epidemiol Psychiatr Sci. 2015;24:341-52.

19. Straiton M, Reneflot A, Diaz E. Immigrants' use of primary health care services for mental health problems. BMC Health Serv Res. 2014;14:341.

20. Straiton ML, Powel K, Reneflot A, Diaz E. Managing Mental Health Problems Among Immigrant Women Attending Primary Health Care Services. Health Care Women Int. 2016;37:118-39.

21. Beiser M, Hou F. Chronic health conditions, labour market participation and resource consumption among immigrant and native-born residents of Canada. Int J Public Health. 2014;59:541-7.

22. Berchet $C$. Health care utilisation in France: An analysis of the main drivers of health care use inequalities related to migration. Rev Epidemiol Sante Publique. 2013;61 Suppl 2:S69-79 [Article in French].

23. Carmona-Alférez MR. Derivaciones a especialistas en atención primaria según lugar de nacimiento de los pacientes (Doctoral thesis). Facultad de Medicina. Universidad Complutense de Madrid (2013). http://eprints.ucm. es/24295/ Accessed 17 Mar 2016. [Article in Spanish]

24. De Luca G, Ponzo M, Rodriguéz Andrés A. Health care utilization by immigrants in Italy. Int J Health Care Finance Econ. 2013;13:1-31.

25. Durbin A, Moineddin R, Lin E, Steele LS, Glazier R. Mental health service use by recent immigrants from different world regions and by non-immigrants in Ontario, Canada: a cross-sectional study. BMC Health Serv Res. 2015;15:336.

26. Gazard B, Frissa S, Nellmus L, Hotopf M, Hatch SL. Challenges in researching migration status, health and health service use: an intersectional analysis of a South London community. Ethn Health. 2015;20:564-93.

27. Gimeno-Feliú LA, Calderón-Larrañaga A, Prados-Torres A, Revilla-López C, Diaz E. Patterns of pharmaceutical use for immigrants to Spain and Norway: a comparative study of prescription databases in two European countries. Int J Equity Health. 2016;15:32.

28. Ramos JM, Navarrete-Muñoz EM, Pinargote H, Sastre J, Seguí JM, Rugero MJ. Hospital admissions in Alicante (Spain): a comparative analysis of foreign citizens from high-income countries, immigrants from low-income countries, and Spanish citizens. BMC Health Serv Res. 2013;13:510.

29. Spinogatti F, Civenti G, Conti V, Lora A. Ethnic differences in the utilization of mental health services in Lombardy (Italy): an epidemiological analysis. Soc Psychiatry Psychiatr Epidemiol. 2015;50:59-65.

30. Tarraf W, Vega W, González HM. Emergency Department Services Use among immigrant and non-immigrant Groups in the United States. J Immigr Minor Health. 2014;16:595-606.

31. Tormo MJ, Salmerón D, Colorado-Yohar S, Ballesta M, Dios S, Martínez-Fernández C, et al. Results of two surveys of immigrants and natives in Southeast Spain: health, use of services, and need for medical assistance. Salud Publica Mex. 2015;57:38-49 [Article in Spanish]. 
32. Verhagen I, Ros WJG, Steunenberg B, Laan W, de Wit NJ. Differences in health care utilisation between elderly from ethnic minorities and ethnic Dutch elderly. Int J Equity Health. 2014;13:125.

33. Almeida LM, Santos CC, Caldas JP, Ayres-de-Campos D, Sias S. Obstetric care in a migrant population with free access to health care. Int I Gynaecol Obstet. 2014;126:244-7.

34. De Back TR, Bodewes AJ, Brewster LM, Kunst AE. Cardiovascular Health and Related Health Care Use of MoluccanDutch Immigrants. PLoS One. 2015;10(9):e0138644.

35. Esscher A, Binder-Finnema P, Bødker B, Högberg U, Mulic-Lutvica A, Essén B. Suboptimal care and maternal mortality among foreign-born women in Sweden: maternal death audit with application of the "migration three delays" model. BMC Pregnancy Childbirth. 2014;14:141.

36. Fosse-Edorh S, Fagot-Campagna A, Detournay D, Bihan H, Gautier A, Dalichampt M, Druet C. Type 2 diabetes prevalence, health status and quality of care among the North African immigrant population living in France. Diabetes Metab. 2014;40:143-50.

37. Franchi C, Baviera M, Sequi M, Cortesi L, Tettamanti M, Roncaglioni MC, et al. Comparison of Health Care Resource Utilization by Immigrants versus Native Elderly People. J Immigr Minor Health. 2016;18:1-7.

38. Garcia-Subirats I, Vargas I, Sanz-Barbero B, Malmusi D, Ronda E, Ballesta M, Vázquez ML. Changes in Access to Health Services of the Immigrant and Native-Born Population in Spain in the Context of Economic Crisis. Int J Environ Res Public Health. 2014;11:10182-201.

39. Gimeno-Feliú LA, Magallón-Botaya R, Macipe-Costa RM, Luzón-Oliver L, Cañada-Millan JL, Lasheras-Barrio M. Differences in the Use of Primary Care Services Between Spanish National and Immigrant Patients. J Immigr Minor Health. 2013;15:584-90.

40. Klaufus LH, Fassaert TJ, de Wit MA. Equity of access to mental health care for anxiety and depression among different ethnic groups in four large cities in the Netherlands. Soc Psychiatry Psychiatr Epidemiol. 2014;49:1139-49.

41. Kerkenaar M, Maier M, Kutalek R, Lagro-Janssen ALM, Ristl R, Pichlhöfer O. Depression and anxiety among migrants in Austria: A population based study of prevalence and utilization of health care services. J Affect Disord. 2013;151:220-8.

42. Lee $\mathrm{CH}$, Choo H, Tai BC. Immigrant status and disparities in health care delivery in patients with myocardial infarction. Int J Cardiol. 2013;166:696-701.

43. Marchesini G, Bernardi D, Miccoli R, Rossi E, Vaccaro O, de Rosa M, et al. Under-treatment of migrants with diabetes in a universalistic health care system: The ARNO Observatory. Nutr Metab Cardiovasc Dis. 2014;24:393-9.

44. Pourat N, Wallace SP, Hadler MW, Ponce N. Assessing Health Care Services Used By California's Undocumented Immigrant Population In 2010. Health Aff. 2014;33:840-7.

45. Smith Nielsen S, Koitzsch Jensen N, Kreiner S, Norredam M, Krasnik A. Utilisation of psychiatrists and psychologists in private practice among non-Western labour immigrants, immigrants from refugee-generating countries and ethnic Danes: the role of mental health status. Soc Psychiatry Psychiatr Epidemiol. 2015;50:67-76.

46. Villarroel N, Artazcoz L. Different Patterns in Healthcare Use among Immigrants in Spain. J Immigr Minor Health. 2015. doi:10.1007/s10903-015-0202-4 [Epub ahead of print].

47. Wang L. Immigrant health, socioeconomic factors and residential neighbourhood characteristics: A comparison of multiple ethnic groups in Canada. Applied Geography. 2014;50:90-8.

48. Wang L, Kwak MJ. Immigration, barriers to healthcare and transnational ties: A case study of South Korean immigrants in Toronto, Canada. Soc Sci Med. 2015;133:340-8.

49. Da Silva RB, Contandriopoulos AP, Pineault R, Tousignant P. A global approach to evaluation of health services utilization: concepts and measures. Healthc Policy. 2011;6:e106-17.

50. Cuadra CB. Right of access to health care for undocumented migrants in EU: a comparative study of national policies. Eur J Public Health. 2012;22:267-71.

51. Andersen and Newman Framework of Health Services Utilization. http://umanitoba.ca/faculties/health_sciences/ medicine/units/community_health_sciences/departmental_units/mchp/protocol/media/Andersen_and_Newman_ Framework.pdf. Accessed 18 Mar 2016.

52. Andersen RM. Revisiting the behavioural model and access to medical care: does it matter? J Health Soc Behav. 1995;36:1-10.

53. Thomson MS, Chaze F, George U, Guruge S. Improving Immigrant Populations' Access to Mental Health Services in Canada: A Review of Barriers and Recommendations. J Immigr Minor Health. 2015;17:1895-905.

54. Llop-Gironés A, Vargas Lorenzo I, Garcia-Subirats I, Aller MB, Vazquez-Navarrete ML. Acceso a los servicios de salud de la población inmigrante en España. Rev Esp Salud Publica. 2014;88:715-34 [Article in Spanish].

55. Norredam M, Nielsen SS, Krasnik A. Migrants' utilization of somatic healthcare services in Europe-a systematic review. Eur J Public Health. 2010;20:555-63.

56. Uiters E, Devillé W, Foets M, Speeuwenberg P, Groenewegen PP. Differences between immigrant and nonimmigrant groups in the use of primary medical care; a systematic review. BMC Health Serv Res. 2009;9:76.

57. Bhugra D. Migration and mental health. Acta Psychiatr Scand. 2004;109:243-58.

58. Reyes-Uruena JM, Noori T, Pharris A, Jansa JM. New times for migrants' health in Europe. Rev Esp Sanid Penit. 2014;16:48-58 [Article in Spanish].

59. Scholz N. The public health dimension of the European migrant crisis. EPRS-European Parliamentary Research Service: Members' Research Service; 2016. http://www.europarl.europa.eu/RegData/etudes/BRIE/2016/573908/ EPRS_BRI\%282016\%29573908_EN.pdf. Accessed: 17 Mar 2016. 